Working Paper/Document de travail 2014-43

\title{
International Transmission Channels of U.S. Quantitative Easing: Evidence from Canada
}

by Tatjana Dahlhaus, Kristina Hess and Abeer Reza 
Bank of Canada Working Paper 2014-43

September 2014

\title{
International Transmission Channels of U.S. Quantitative Easing: Evidence from Canada
}

\author{
by \\ Tatjana Dahlhaus, Kristina Hess and Abeer Reza \\ International Economic Analysis Department \\ Bank of Canada \\ Ottawa, Ontario, Canada K1A 0 G9 \\ Corresponding author: reza@bankofcanada.ca
}

Bank of Canada working papers are theoretical or empirical works-in-progress on subjects in economics and finance. The views expressed in this paper are those of the authors. No responsibility for them should be attributed to the Bank of Canada. 


\section{Acknowledgements}

We thank Christiane Baumeister, Jean-Philippe Cayen, Michael Ehrmann, Robert Lavigne, Eric Santor, and seminar participants at the Bank of Canada, the 48th Annual Conference of the Canadian Economic Association, and the International Association for Applied Econometrics 2014 Annual Conference for helpful comments and suggestions. All errors and omissions are our own. 


\begin{abstract}
The U.S. Federal Reserve responded to the great recession by reducing policy rates to the effective lower bound. In order to provide further monetary stimulus, they subsequently conducted large-scale asset purchases, quadrupling their balance sheet in the process. We assess the international spillover effects of this quantitative easing program on the Canadian economy in a factor-augmented vector autoregression (FAVAR) framework, by considering a counterfactual scenario in which the Federal Reserve's long-term asset holdings do not rise in response to the recession. We find that U.S. quantitative easing boosted Canadian output, mainly through the financial channel.

JEL classification: C32, E52, E58, F42, F44

Bank classification: Transmission of monetary policy; International topics; Monetary policy framework
\end{abstract}

\title{
Résumé
}

En réaction à la Grande Récession, la Réserve fédérale américaine a réduit son taux directeur à sa valeur plancher. Afin d'accentuer la détente monétaire, la banque centrale américaine a par la suite mis en œuvre des achats massifs d'actifs, ce qui a eu pour effet de quadrupler la taille de son bilan. Les auteurs évaluent les effets de débordement de ce programme d'assouplissement quantitatif à l'international par le prisme de l'économie canadienne, à l'aide d'un modèle vectoriel autorégressif enrichi de facteurs (FAVAR). Ils examinent ainsi un scénario hypothétique dans le cadre duquel les actifs à long terme détenus par la Réserve fédérale n’auraient pas augmenté en réponse à la récession. Les auteurs constatent que les mesures d'assouplissement quantitatif adoptées par les ÉtatsUnis ont stimulé la production canadienne, principalement par le canal de l'activité financière.

Classification JEL : C32, E52, E58, F42, F44

Classification de la Banque : Transmission de la politique monétaire; Questions

internationales; Cadre de la politique monétaire 


\section{Introduction}

In the aftermath of the global financial crisis, many central banks turned to quantitative easing (QE), or large-scale purchases of long-term assets, as a means to provide monetary stimulus when their conventional policy interest rates became stuck at their respective effective lower bounds. The U.S. Federal Reserve, in particular, responded to the postcrisis recession by reducing its short-term policy rate to near zero, and subsequently attempting to bring down long-term interest rates by purchasing long-term assets in an unprecedented scale, effectively quadrupling the size of its balance sheet by the end of 2013 in the process (see Figure 1). ${ }^{1}$ Since then, the economic literature has focused on explaining the transmission mechanism of QE (Bernanke [2012]), and quantifying its impact on the domestic economies of countries implementing such policies (Lenza et al. [2010], Kapetanios et al. [2012], Baumeister and Benati [2013]). Given the globally interconnected markets in which the crisis unfolded, however, it is reasonable that the unprecedented policy reaction to the crisis may also have large international spillovers. Yet, there is a dearth of analysis on the international transmission of QE to the real economies of countries that did not adopt such programs. In this paper, we address this gap by assessing the spillover of the Fed's QE program to the real economy of a non-QE country, namely, Canada.

Specifically, we (a) quantify the effect of the Fed's long-term asset purchases on the Canadian economy, and (b) identify the principal channels of international transmission in a two-country factor-augmented vector autoregression (FAVAR) framework by considering a counterfactual scenario where the Fed's long-term asset holdings do not rise in response to the recession.

Although the effect of QE on the U.S. domestic economy is thought to be stimulative under the zero lower bound, it is unclear whether its effect on foreign economies would be unambiguously expansionary. Whether by signaling the Fed's intention to keep short-term rates low for an extended period (Woodford [2012]), or by rebalancing imperfectly substitutable financial assets in investor portfolios (Bernanke [2012]), large-scale purchases of long-maturity assets by the Fed would increase asset prices and reduce bond yields. Higher asset prices would then boost consumption through wealth effects. At the same time, a rise in asset prices relative to the replacement cost of capital would boost investment, as would a reduction in the user cost of capital due to a drop in long-term interest rates.

Standard economic theory, however, provides ambiguous implications for the international spillover of monetary easing (Rogoff [2002]). Through the expenditure-switching effect, a monetary expansion in the United States would depreciate the home currency and deteriorate its terms of trade, making home goods cheaper for foreigners. The re-

\footnotetext{
${ }^{1}$ Although the first wave of asset purchases was aimed at preventing the seizing up of credit markets and included short-term emergency lending to financial firms, purchases of agency debt and asset-backed securities, subsequent programs targeted long-term mortgage-backed securities and government bonds in an effort to reduce long-term interest rates. In this paper, we assess the effects of the latter aspect of QE. For a discussion on the difference between the two aspects of balance-sheet expansion, see Lenza et al. [2010], and Kozicki et al. [2011].
} 
sulting increase in home country net exports would then detract from the real output of the foreign economy. The income-absorption effect, on the other hand, implies that as long as expansionary monetary policy in the home country drives up domestic income, home demand for imports would rise, boosting the economy of foreign exporters. Finally, in the presence of global financial market integration, any increase in asset prices and reductions in yields in the domestic financial market resulting from QE may be reflected by similar movements in corresponding foreign financial market variables, ${ }^{2}$ which in turn would boost foreign consumption and investment through the same mechanism as it does in the domestic case. Therefore, whether Canada benefits from the U.S. expansion through QE depends on which of these effects dominate, and is an empirical question that we attempt to answer here.

Our interest in identifying the international transmission channels of QE makes FAVAR (Bernanke et al. [2005], Boivin and Giannoni [2007], Charnavoki and Dolado [2014]) the appropriate framework to consider, since it allows us to simultaneously assess the dynamic interactions between a large number of financial and real variables.

We choose Canada as an important case to highlight international transmission channels for a number of reasons. First, its strong trade and financial ties with the United States makes it reasonable to expect spillovers to be strong and easily observable. Second, the Bank of Canada did not implement QE, since the pre-crisis resilience of the Canadian financial sector prevented severe financial contagion during the crisis. ${ }^{3}$ Figure 1 shows, however, that despite virtually no change in the amount of long-term assets in the Bank of Canada's balance-sheet holdings, ${ }^{4}$ long-term spreads in Canada fell at the same time as its U.S. counterpart. Third, Canada is a small open economy with a floating exchange rate, with a long tradition of independent monetary policy, and availability of quality data. The latter is of particular practical importance when considering a FAVAR analysis. Finally, Canada is also a commodity exporter, allowing for a richer exploration of possible spillover channels of QE. For example, even when the income-absorption effect dominates in the United States, higher import demand for Canadian energy products may drive up the Canadian exchange rate, putting the non-energy sectors at a disadvantage from an export price point of view. ${ }^{5}$

\footnotetext{
${ }^{2}$ Indeed, Fratzscher et al. [2013] find that QE boosted equity prices worldwide, including in Canada, while Bauer and Neely [2012] show that long-term Canadian yields decreased following U.S. large-scale asset purchase announcements.

${ }^{3}$ Note that Canada provided direct qualitative signals on the future path of short-term rates through forward guidance statements, as did the United States (Fay and Gravelle [2008]). Moreover, the Bank of Canada provided term-liquidity facilities to financial market participants to stabilize the financial system and limit the repercussions of the crisis to the Canadian economy (Zorn et al. [2009]).

${ }^{4}$ The increase in the other-asset category seen from 2011 onwards reflects the Canadian federal government's debt management strategy. Specifically, in the 2011 federal budget, the government decided to hold prudential assets in the form of cash and short-term treasuries that would allow it to operate for one month in case its regular access to financial markets were hindered. For details, see the government's prudential liquidity-management plan delineated in the budget document, http://www.budget.gc.ca/2011/plan/anx2-eng.html. Taking a purely monetarist approach, however, one might interpret the rise in the total assets of the Bank of Canada's balance sheet as a monetary expansion (Gambacorta et al. [2012]).

${ }^{5}$ Using a FAVAR approach, Charnavoki and Dolado [2014] find that a higher exchange due to high
} 
Since the beginning of the foray into unconventional policy, a number of studies have attempted to quantify the effects of QE on domestic financial markets (Gagnon et al. [2011], Krishnamurthy and Vissing-Jorgensen [2011]), and domestic real economies of countries conducting such policies (cf. Lenza et al. [2010] for an analysis on the euro area, Kapetanios et al. [2012] for the United Kingdom, Baumeister and Benati [2013] for the United States and United Kingdom, Schenkelberg and Watzka [2013] for Japan, and Gambacorta et al. [2012] for an international comparison), as well as on the spillovers of QE to international financial markets (Fratzscher et al. [2013], Bauer and Neely [2012]). To the best of our knowledge, this is the only paper that attempts to assess the effects of international spillovers of QE on the real economy. In this sense, it complements the literature on the real spillovers of conventional monetary policy (Kim [2001], Kazi et al. [2013]).

Our approach differs from existing studies on the effects of QE in two important ways. First, while earlier studies proxy U.S. policy through its intended, but unobserved, effects on long-term rates, we directly measure policy action through the observable expansion of the Fed's balance sheet. With limited information available at the onset of the implementation of QE, early papers on the topic take findings from event studies on financial market reactions to Fed announcements as given, and construct counterfactual scenarios where the absence of QE is proxied through higher long-term rates. ${ }^{6} \mathrm{We}$, on the other hand, measure QE as the Fed's balance-sheet holdings of long-term assets, and construct a counterfactual scenario where these holdings are not increased in reaction to the great recession. Our measure takes advantage of 19 quarters of observable data, and is agnostic about the effect on long-term rates. Note, however, that we retain the focus on long-term asset purchases, rather than the increase in the monetary base or the total size of the Fed's balance sheet as considered by Gambacorta et al. [2012]. ${ }^{7}$

Second, we estimate a two-country FAVAR with coefficient restrictions which allows us to study the transmission of U.S. policy through dynamic interactions between a large number of financial and real variables, while at the same time restricting U.S. policy from being influenced by movements in Canadian economic variables. We believe this is the appropriate framework for studying relationships between a large country such as the United States and a small open economy such as Canada (Charnavoki and Dolado

energy prices negatively impacts the non-energy sector output only after a negative energy supply shock, while it positively impacts non-energy sector output following a positive global demand shock. This finding is mirrored by Dorich et al. [2013], who use an estimated dynamic stochastic general-equilibrium (DSGE) framework.

${ }^{6}$ Looking at financial market reaction within a short time-window of the Fed announcements regarding QE, Gagnon et al. [2011] and Krishnamurthy and Vissing-Jorgensen [2011] suggest that QE lowered long-term treasury yields by between 30 and 100 basis points. Baumeister and Benati [2013] accordingly construct their counterfactual scenario of a world without QE as one where long-term yields are 100 basis points higher. In a similar event study, Joyce et al. [2011] find that QE announcements in the United Kingdom reduced long-term government bond rates by 100 basis points. This, in turn, serves as the basis for the counterfactual scenario considered by Kapetanios et al. [2012].

${ }^{7}$ Interpreting QE as an increase in the total size of the Fed's balance sheet or monetary base espouses a purely monetarist view that relies on the structural stability of the money multiplier and the velocity of money (Woodford [2012]). 
$[2014])$.

We find that the implementation of QE increases U.S. output by about 2.3 percent and Canadian output by 2.2 percent on average between 2008Q4 and 2013Q3, when compared with the no-QE counterfactual scenario. Because of QE, U.S. long-term spreads decline, and asset prices rise, boosting both investment and consumption, though the latter is not statistically significant. The transmission to Canada occurs mostly through the financial market. Although Canada did not implement QE, long-term spreads in Canada fall, and asset prices in the Canadian stock market rise. QE also leads to higher oil prices, an improvement in the Canadian terms of trade and an appreciation of the Canadian nominal exchange rate vis-à-vis the United States, consistent with the commodity currency effect documented by Charnavoki and Dolado [2014] and Dorich et al. [2013].

In other words, financial market integration results in Canadian interest rates and asset prices moving in the same direction as those in the United States following the implementation of QE. Along with the effects of improved terms of trade, spillovers from the financial channel bolster the domestic Canadian economy, driving up Canadian demand for imports, while the appreciation of the Canadian dollar makes imports cheaper. As a consequence, net exports fall, despite the fact that Canadian exports increase in most product categories, consistent with a stronger U.S. economy. Our finding that the financial channel dominates the trade channel in transmitting positive spillovers from a U.S. monetary expansion is consistent with the transmission of conventional monetary policy documented by Kim [2001] using a small structural vector autoregression.

The rest of the paper is organized as follows. Section 2 describes the two-country FAVAR set-up, as well as the data and estimation process. Section 3 describes the counterfactual set-up and the results of the exercise for both aggregate real and financial variables, as well as some disaggregated variables. We provide some robustness analysis in section 4 , including a qualitative look at the transmission mechanism for a conventional monetary policy shock to the U.S. policy rate. Section 5 concludes.

\section{Empirical Framework}

We choose a FAVAR approach (Bernanke et al. [2005] and Boivin and Giannoni [2007]) to assess the different international transmission channels of QE. This is the appropriate framework to consider, since it allows us to simultaneously compare the effect of QE on a broad set of financial and real variables from Canada and the United States, while taking into account the dynamic interactions between them. We explain our empirical set-up, describe the data and discuss the estimation method below.

\section{$2.1 \quad$ Empirical model}

Our FAVAR specification contains two country-specific blocks. Following Charnavoki and Dolado [2014], we impose two restrictions to reflect the small open-economy nature of Canada. First, by imposing block-zero restrictions on the VAR coefficients, we ensure that movements in Canadian factors do not influence movements in U.S. factors. Second, 
by specifying that Canadian time series load onto both U.S. and Canadian factors, we allow for a strong co-movement between real and financial variables of both countries, while keeping unobserved factors orthogonal to each other.

The one-directional nature of the relationship between these two countries inherent in our modeling choice is motivated by the following observations from international trade and financial flow data. First, Canada is highly dependent on the United States for its international trade, while the reverse is not true. On average, 84 percent of total Canadian exports between 2000 and 2007 were destined for the United States. However, this accounted for only 17 percent of total U.S. imports. Table 1 shows that this disparity is true for Canadian imports as well, and holds across all product categories. International financial flows between the two countries show a similar pattern. Table 2 shows that 47 percent of Canadian portfolio and direct investments abroad are in the United States, while almost 60 percent of foreign direct and portfolio investments in Canada come from the United States. In particular, about 80 percent of foreign investments in Canadian equity are held by U.S. investors. Finally, Table 3 shows that both financial markets and real economies of the two countries are strongly and persistently correlated in business cycle frequencies. This suggests that the Canadian economy is highly responsive to movements in U.S. economic and policy variables, while the reverse may not be true. This is reflected in our empirical framework described below.

The first block in our FAVAR model contains a vector of unobservable factors, $\mathbf{F}_{t}^{U S, F}$, that summarizes information about the U.S. economy, and a vector of observable policy variables, $\mathbf{Y}_{t}^{U S}$, that summarizes the U.S. monetary policy stance. $\mathbf{F}_{t}^{U S}=\left(\mathbf{F}_{t}^{U S, F}, \mathbf{Y}_{t}^{U S}\right)$. In our case, the policy variables are the effective federal funds rate and our measure of QE - total long-term asset holdings in the Fed's balance sheet. The second block consists of Canada-specific unobservable factors, $\mathbf{F}_{t}^{C A}$, that are orthogonal to the U.S. factors.

The U.S. and Canadian data load onto the factors as follows:

$$
\left[\begin{array}{l}
\mathbf{X}_{t}^{U S} \\
\mathbf{X}_{t}^{C A}
\end{array}\right]=\left[\begin{array}{cc}
\boldsymbol{\Lambda}_{U S}^{U S} & \mathbf{0} \\
\boldsymbol{\Lambda}_{U S}^{C A} & \boldsymbol{\Lambda}_{C A}^{C A}
\end{array}\right]\left[\begin{array}{l}
\mathbf{F}_{t}^{U S} \\
\mathbf{F}_{t}^{C A}
\end{array}\right]+\left[\begin{array}{l}
\mathbf{u}_{t}^{U S} \\
\mathbf{u}_{t}^{C A}
\end{array}\right]
$$

where $\mathbf{X}_{t}^{U S}$ and $\mathbf{X}_{t}^{C A}$ are data for the U.S. and Canadian economies, $\boldsymbol{\Lambda}_{U S}^{j}=\left(\boldsymbol{\Lambda}_{U S, F}^{j} \boldsymbol{\Lambda}_{U S, Y}^{j}\right)$ are the loading matrices corresponding to the unobservable and observable U.S. factors, and $\boldsymbol{\Lambda}_{C A}^{C A}$ denotes the loading matrix for the Canadian factors that are orthogonal to the U.S. ones. As we can see, the Canadian data load onto both U.S. and Canada-specific factors. $\mathbf{u}_{t}^{U S}$ and $\mathbf{u}_{t}^{C A}$ are vectors of idiosyncratic disturbances.

We model the dynamics of the factors as a restricted VAR (see, e.g., Charnavoki and Dolado [2014]):

$$
\left[\begin{array}{l}
\mathbf{F}_{t}^{U S} \\
\mathbf{F}_{t}^{C A}
\end{array}\right]=\left[\begin{array}{cc}
\mathbf{b}_{11}(L) & \mathbf{0} \\
\mathbf{b}_{21}(L) & \mathbf{b}_{22}(L)
\end{array}\right]\left[\begin{array}{l}
\mathbf{F}_{t-1}^{U S} \\
\mathbf{F}_{t-1}^{C A}
\end{array}\right]+\mathbf{e}_{\mathbf{t}},
$$

where $\mathbf{b}_{i j}(L)$ are lag polynomials of finite order $p$ and $\mathbf{e}_{t}$ denotes the reduced-form residuals. The block of zeros in the coefficient matrix prevents movements in Canadian factors to influence those in the United States. As argued above, we believe that this restriction adequately captures the small open-economy nature of Canada. Relaxing this restriction, however, does not alter our main findings presented below. Combining equations (1) and 
(2), one-step-ahead forecasts for each series contained in the data set can be obtained from the following equation:

$$
\left[\begin{array}{l}
\mathbf{X}_{t}^{U S} \\
\mathbf{X}_{t}^{C A}
\end{array}\right]=\left[\begin{array}{cc}
\boldsymbol{\Lambda}_{U S}^{U S} & \mathbf{0} \\
\boldsymbol{\Lambda}_{U S}^{C A} & \boldsymbol{\Lambda}_{C A}^{C A}
\end{array}\right]\left[\begin{array}{cc}
\mathbf{b}_{11}(L) & \mathbf{0} \\
\mathbf{b}_{21}(L) & \mathbf{b}_{22}(L)
\end{array}\right]\left[\begin{array}{l}
\mathbf{F}_{t-1}^{U S} \\
\mathbf{F}_{t-1}^{C A}
\end{array}\right]+\epsilon_{\mathbf{t}}
$$

\subsection{Data}

We use quarterly data from 122 U.S. and 149 Canadian series ranging from 1983Q1 through 2013Q3. The start date is restricted by the availability of Canadian disaggregated data. The U.S. series include real data from national income, industrial production, employment by industry, as well as data on housing starts and sales, manufacturers' orders and inventory, and a number of different price indexes. Movements in the financial sector are captured through stock prices, nominal and real exchange rates, interest rates of varying maturity, bond prices, monetary aggregates, and commercial bank balancesheet and lending conditions. We also include confidence indexes from the Conference Board and University of Michigan surveys on business sentiment. The QE variable represents the Federal Reserve's balance-sheet holdings of mortgage-backed securities and treasury bonds with maturities of more than five years. A more detailed discussion on the choice of this variable is provided in section 3 while describing the counterfactual set-up.

The Canadian series include real data on national accounts, Canadian exports and imports by product and by regional destination, flows from the balance of payments account, and industry-level GDP and employment. We also include Canadian house prices and housing starts, and a number of relative price and oil price indexes. Movement in the financial sector is captured through the Toronto Stock Exchange (TSX) price index, nominal and trade-weighted real exchange rates, interest rates of various maturities, as well as balance-sheet conditions from commercial banks and private industry. We capture Canadian business confidence by the Conference Board confidence index.

Most of our data series, both U.S. and Canadian, are downloaded via HAVER analytics. We construct the industry-level GDP for Canada by combining information from tables 379-0027 and 379-0031 from the Canadian Socioeconomic Information Management (CANSIM) database maintained by Statistics Canada. ${ }^{8}$ The series are transformed to induce stationarity, and standardized before estimation. For the benchmark case presented in section 3.2, we transform our measure of QE by taking differences in levels, and consider differences in logs in section 4. The appendix provides detailed descriptions, sources and transformation codes for all series considered.

\footnotetext{
${ }^{8}$ Statistics Canada discontinued table 379-0027 in 2012Q4, where real industry-level GDP is measured in 2002 Canadian dollars, and replaced it with table 379-0031, where data were measured in 2007 dollars and start in 1997Q1. We construct our GDP series by taking data from the latter table, and growing them out backwards using the growth rate of corresponding variables from the former table.
} 


\subsection{Estimation}

Following Bernanke et al. [2005], we estimate the FAVAR in two steps. First, the unobserved factors $\mathbf{F}_{t}^{U S, F}$ and $\mathbf{F}_{t}^{C A}$ are estimated through principal components from our data sets $\mathbf{X}_{t}^{U S}$ and $\mathbf{X}_{t}^{C A}$. Second, both unobserved and observed policy variables are then cast into a restricted VAR model.

The unobservable U.S. factors are rotated to be orthogonal to the observed policy variables as follows. First, we start by extracting $K^{U S}$ factors from the U.S. data set $\mathbf{X}_{t}^{U S}$ as the largest $K^{U S}$ principal components. We then extract the same number of factors from a subset of our data set that contain variables which do not respond to policy changes contemporaneously, i.e., slow-moving variables. The full set of factors are then regressed on the set of slow-moving factors and the set of fast-moving policy variables, $\mathbf{Y}_{t}^{U S}$. The final set of factors, $\hat{\mathbf{F}}_{t}^{U S, F}$, are estimated as a rotation of the original factors that are orthogonal to $\mathbf{Y}_{t}^{U S}{ }^{9}$

We allow Canadian data, $\mathbf{X}_{t}^{C A}$, to load onto both U.S. and Canadian factors, with loading matrices $\boldsymbol{\Lambda}_{U S}^{C A}$ and $\boldsymbol{\Lambda}_{C A}^{C A}$, respectively. We estimate the Canadian factors following the iterative procedure employed by Charnavoki and Dolado [2014] in order to control for the effect of the U.S. factors in the Canadian block. Again, we start by extracting $K^{C A}$ factors from the Canadian data set as the largest $K^{C A}$ principal components. Given this initial estimate of the Canadian factors, $\hat{\mathbf{F}}_{t}^{C A(0)}$, we iterate through the following steps until convergence is achieved:

1. Regress $\mathbf{X}_{t}^{C A}$ on $\hat{\mathbf{F}}_{t}^{C A(j)}$ and the estimates of the U.S. factors, $\hat{\mathbf{F}}_{t}^{U S}=\left[\hat{\mathbf{F}}_{t}^{U S, F}, \mathbf{Y}_{t}^{U S}\right]$, to obtain $\hat{\Lambda}_{U S}^{C A(j)}$.

2. Calculate $\tilde{\mathbf{X}}_{t}^{C A(j)}=\mathbf{X}_{t}^{C A}-\hat{\boldsymbol{\Lambda}}_{U S}^{C A(j)} \hat{\mathbf{F}}_{t}^{U S}$.

3. Obtain $\hat{\mathbf{F}}_{t}^{C A(j+1)}$ as the first $K^{C A}$ principal components of $\tilde{\mathbf{X}}_{t}^{C A(j)}$.

4. Return to step 1. The algorithm stops when the difference between $\hat{\mathbf{F}}_{t}^{C A(j+1)}$ and $\hat{\mathbf{F}}_{t}^{C A(j)}$ is sufficiently small.

Different versions of the Bai and Ng [2002] criteria suggest between six and ten factors for the U.S. block and four to eight factors for the Canadian block. We choose six factors for the U.S. block (including the policy variables) and four factors for the Canadian block. Our main message below, however, is robust to any combination of four to ten factors. Using these factors, we estimate equation (2) via restricted ordinary least squares to incorporate the block-zero restriction. We choose only one lag for the VAR to take into account our relatively small sample size.

\section{International Transmission of QE}

Using the empirical set-up described above, we estimate the effect of QE as the difference between two conditional forecasts: one corresponding to the policy scenario, where

\footnotetext{
${ }^{9}$ See Bernanke et al. [2005] for details.
} 
the Fed's long-term asset holdings follow the path observed in data, and the other, the counterfactual no-policy scenario, where the Fed's holding of long-term assets does not increase in response to the great recession. In this section, we first describe our counterfactual set-up, and then discuss the results of our analysis.

\subsection{Counterfactual set-up}

Although the Federal Reserve announced purchases of mortgage-backed and long-term treasury securities in a staggered manner since the beginning of the financial crisis, ${ }^{10}$ actual purchases occurred gradually. Figure 1 shows the rise in long-term asset holdings (holdings of mortgage-backed securities and treasury securities of maturity higher than five years) in the Fed balance sheet, along with the policy rate and the 10-year treasury yield.

For our counterfactual, we construct a no-policy scenario where this increase in longterm asset holdings does not occur. We therefore espouse a view that anticipated increases in long-term asset holdings have an effect on the economy. We believe that this view is somewhere between Gambacorta et al. [2012], who focus on an unanticipated increase in the Fed's balance sheet, and Woodford [2012], who considers that the announcements themselves contain all relevant information about the Fed's policy actions. In our benchmark case, we generate an unconditional forecast of the Fed's long-term asset holdings from equation (2) using pre-recession values of the factors. This gives us a path for the $\mathrm{QE}$ variable that is consistent with pre-recession dynamics, but one that does not increase in response to the recession. Our no-policy counterfactual is then generated as the expected value of our variables of interest conditional upon this counterfactual path of the Fed's asset holdings. This approach is similar to Lenza et al. [2010]. ${ }^{11}$ We also consider an alternative scenario where the QE variable is projected using its pre-recession trend growth rate, and find similar results as our benchmark case. The benchmark conditional forecasts for the policy and the no-policy scenarios are calculated as follows.

1. Policy scenario: Using a full-sample estimate of equations (1) and (2), produce a forecast from 2008Q4 until 2013Q3, conditional on the actual path of both the

\footnotetext{
${ }^{10}$ In November 2008, the Federal Reserve announced purchases of $\$ 600$ billion worth of mortgagebacked securities. By March 2009, the Fed's holdings of bank debt, mortgage-backed securities and treasury notes reached $\$ 1.75$ trillion. Purchases of long-term treasury securities worth $\$ 600$ billion were announced in November 2010, and a rebalancing of the Fed's portfolio away from short-term and toward long-term treasury securities worth $\$ 400$ billion was announced in September 2011. In September 2012, the Fed announced purchases of mortgage-backed securities worth $\$ 40$ billion per month, and renewal of the portfolio rebalancing scheme toward long-term securities. In December 2012, the Fed increased purchases of mortgage-backed securities from $\$ 40$ to $\$ 85$ billion per month. Finally, in June 2013, the Fed announced a "tapering" of the Fed's asset purchases.

${ }^{11}$ In contrast, Kapetanios et al. [2012] and Baumeister and Benati [2013] consider a counterfactual set of coincident structural shocks, identified through sign restrictions, that move spreads a certain amount higher than observed, while keeping the federal funds rate at the zero lower bound. By conditioning on a particular path of a policy variable, we are spared from imposing a structural interpretation on the set of shocks that represent the Fed's observed policy action.
} 
QE variable $x_{t}^{*, Q E}$ and the effective federal funds rate, $x_{t}^{*, F F}$ :

$$
\hat{\mathbf{X}}_{T+h}=E_{T}\left(\mathbf{X}_{T+h} \mid \mathbf{B}(L), \mathbf{F}_{0} \ldots \mathbf{F}_{T+h}, x_{T+h}^{*, Q E}, x_{T+h}^{*, F F}\right)
$$

for $T+h=2008$ Q4...2013Q3. This is the policy scenario.

2. No-policy scenario: To produce forecasts under the no-policy scenario, first generate a counterfactual path of the QE variable. Second, obtain conditional forecasts using this path and a full sample estimate of equations (1) and (2).

(a) We generate the counterfactual path of the QE variables in two alternative ways.

i. Estimate the restricted regression (Equation (2)) using estimated factors through 2008Q3:

$$
\begin{aligned}
\mathbf{F}_{t} & =\mathbf{B}^{1}(L) \mathbf{F}_{t-1}+\mathbf{e}_{t} \\
t & =1983 \mathrm{Q} 1 \ldots 2008 \mathrm{Q} 3 .
\end{aligned}
$$

Produce an unconditional forecast for the remainder of the sample, and save the path of the QE variable $\tilde{x}_{T+h}^{Q E} \in \tilde{\mathbf{X}}_{T+h}=E_{T}\left(\mathbf{X}_{T+h} \mid \mathbf{B}^{1}(L), \mathbf{F}_{0} \ldots \mathbf{F}_{T+h}\right)$ for $T+h=2008 \mathrm{Q} 4 \ldots 2013 \mathrm{Q} 3$. This gives us the counterfactual path of the QE variable, which is used as our benchmark.

ii. Construct a counterfactual path for the QE variable where it grows according to a linear and quadratic pre-QE time trend. That is, to obtain a path for $T+h=2008$ Q4...2013Q3 apply the trend for $t=1983 \mathrm{Q} 1 \ldots 2008 \mathrm{Q} 3$. This gives us the counterfactual path of the QE variable, which is used for robustness.

(b) Construct a counterfactual forecast from 2008Q4 until 2013Q3, conditional on the actual path of the effective federal funds rate, $x_{T+h}^{*, F}$, and the counterfactual path of the QE variable, $\tilde{x}_{T+h}^{Q E}$, constructed above:

$$
\tilde{\mathbf{X}}_{T+h}=E_{T}\left(\mathbf{X}_{T+h} \mid \mathbf{B}, \mathbf{F}_{0} \ldots \mathbf{F}_{T+h}, \tilde{x}_{T+h}^{Q E}, x_{T+h}^{*, F F}\right)
$$

for $T+h=2008 \mathrm{Q} 4 \ldots 2013 \mathrm{Q} 3$. This is the no-policy counterfactual scenario.

3. The difference between $\hat{\mathbf{X}}_{T+h}$ and $\tilde{\mathbf{X}}_{T+h}$ is then the effect of QE.

Note that, while we directly measure policy action through 19 quarters of observable expansion of the Fed's balance sheet, we remain agnostic about the quantitative effect (or, even, the direction of change) of $\mathrm{QE}$ on long-term rates. In contrast, early studies estimating the effect of QE proxy central bank policy through its intended, but unobserved, effect on long-term rates. Gagnon et al. [2011] and Krishnamurthy and Vissing-Jorgensen [2011] use event-study methods on financial markets to estimate that early Fed announcements related to QE reduced long-term yields by 30 to 107 basis points 
(bps). With limited information available at the onset of the implementation of this novel policy paradigm, early studies on the effect of QE take these estimates of announcement effects on long-term yields as given, and construct counterfactual scenarios where, in the absence of QE, long-term spreads are higher by the same amount (Baumeister and Benati [2013], Kapetanios et al. [2012]).

\subsection{Results}

Figures 2 and 3 show the effect of QE for a key set of variables for the United States and Canada, respectively. The solid line represents the difference between the two conditional point forecasts, and the dashed lines show the 68 percent residual bootstrap bands from the counterfactual exercise described above. Note that although these figures resemble traditional impulse responses, they are not so. Instead, they represent the difference between the policy scenario and the no-policy scenario at each quarter of the forecast horizon. When noted, results are expressed in percentage difference from the no-policy scenario.

A number of key results emerge from our exercise. First, as Figure 2 suggests, QE boosts domestic U.S. GDP by lowering long-term spreads. Compared to the counterfactual scenario, on average between 2008Q4 and 2013Q3, the increase in long-term asset holdings in the Fed balance sheet reduces the 10-year treasury spread by 82 bps, and increases GDP by 2.3 percent and the personal consumption expenditure price index by 0.5 percent. Note that our result of a positive impact of QE on U.S. GDP is not derived from an explicit assumption of a reduced long-term spread. Rather, the latter arises as an endogenous response to an increase in the Fed's long-term asset holdings. The magnitude of decline in long-term spreads is comparable to Neely [2010], Krishnamurthy and Vissing-Jorgensen [2011], and Bauer and Neely [2012], who find, using different empirical techniques, that long-term treasury yields fell by 88, 107, and $123 \mathrm{bps}$, respectively, due to the Fed's 2009 asset purchases, and to Gagnon et al. [2011], who find that the same purchases resulted in a reduction in the 10-year term premium by 30 to 100 bps. Our effect on GDP is also in the same order of magnitude as Chung et al. [2012], who find that a cumulative 70 bps drop in the term premium due to QE resulted in real GDP being higher by 3 percentage points by early 2012. Moreover, the higher personal consumption price under the QE scenario than under the no-policy scenario suggests that our counterfactual exercise does not generate a price puzzle for QE that is often found in the literature on conventional monetary policy shocks.

The domestic transmission of QE occurs largely along the lines explained by Bernanke [2012]. Asset prices (the S\&P 500 index), consumer confidence (Conference Board indicator), the banking sector's willingness to lend (Federal Reserve's senior loan officer survey), and commercial and industrial loans all increase, while corporate spreads (BAA - AAA) decline. This raises U.S. investment, and, to a lesser extent, consumption. ${ }^{12}$

\footnotetext{
${ }^{12}$ To put our quantitative results into better perspective, consider the following two examples: in 2013Q3, real investment and the S\&P price index in our QE scenario are estimated to be 38 and 162 percent higher than in our no-policy scenario, respectively. Data show that in 2013Q3, investment was
} 
Second, Figure 3 shows that the spillover effect of QE on Canada is positive, and of the same order of magnitude as in the United States. In the financial market, the increase in the Fed's long-term asset holdings reduces the 10-year Canadian government bond spread by 30 bps on average between 2008Q4 and 2013Q3, compared to the counterfactual. In the goods market, Canadian GDP increases by 2.2 percent, and the consumer price index by 0.5 percent, on average in the same period. In comparison, Bauer and Neely [2012] find that the 2009 asset purchases by the Fed reduced Canadian 10-year yields by 66 bps.

Third, the transmission of QE to Canada occurs mainly through financial channels. Due to strong financial integration, the Canadian corporate spread (Canadian 3-month corporate bond yield - Canadian 3-month government bond yield) falls, while both Canadian asset prices (TSX index), and consumer confidence (Conference Board index) rise alongside their U.S. counterparts. Consequently, both Canadian consumption and investment increase. Our finding that QE in the U.S. transmits to Canada through the financial rather than the trade channel complements a similar finding by Kim [2001] for a conventional monetary policy shock.

Importantly, compared with the no-policy scenario, QE leads to higher oil prices (Brent prices are shown in Figure 3), an improvement in the Canadian terms of trade and an appreciation of the Canadian nominal exchange rate vis-à-vis the United States. This is consistent with the commodity currency effect documented by Charnavoki and Dolado [2014] and Dorich et al. [2013]. Positive spillovers from improved terms of trade bolster Canadian income and wealth, and work in the same direction as the spillovers from the financial channel in raising Canadian consumption and investment.

Finally, net exports fall. However, this is due to higher imports from a comparatively stronger Canadian domestic demand, rather than lower exports to the United States. Looking closer at net exports, however, we find two important trends that contradict a purely expenditure-switching view. First, as we see in Figure 3, although Canadian global net exports decline compared to the counterfactual, net exports destined to the United States increase, or at least stay the same, during that period, suggesting that the decline in net exports is due to trade with the rest of the world. Second, Figures 4 and 5 show that the decline in Canadian net exports is due not to a fall in exports, but rather to stronger imports in almost all product categories.

In other words, financial market integration results in Canadian interest rates and asset prices moving in the same direction as those in the United States following the implementation of QE. Along with the effects of improved terms of trade, spillovers from the financial channel bolster the domestic Canadian economy, driving up Canadian demand for imports, while the appreciation of the Canadian dollar makes imports cheaper. As a consequence, net exports fall, despite the fact that Canadian exports increase in most product categories, consistent with a stronger U.S. economy.

Finally, Figure 6 shows the impact of QE on Canadian GDP by industry. As a commodity-exporting country, Canada generally benefits from a rise in global oil prices. At the same time, the commodity currency effect implies that increased demand for

45.6 percent and the S\&P index was 107 percent higher than their recessionary troughs, which occurred in 2009Q3 and 2009Q1, respectively. 
oil also appreciates the Canadian exchange rate, which may make other industries noncompetitive. Thus, the gains in the oil-producing industry might come at the expense of other industries. This trade-off is often referred to as Dutch disease. As Figure 6 shows, however, GDP in all industries, except for the arts, entertainment and recreation, increase due to the implementation of QE. As such, we do not find any evidence of Dutch disease due to unconventional U.S. monetary policy.

To summarize, we find that the implementation of QE in the United States benefits Canada almost to the same extent as it does the U.S. domestic economy. This spillover into Canada occurs mainly from the financial channel, as integrated financial markets make Canadian asset prices and interest rates move in the same direction as their U.S. counterparts. This effect is also bolstered through stronger Canadian terms of trade. The Canadian exchange rate appreciates, generating leakages through reduced net exports. However, these leakages were a consequence of stronger Canadian demand for imports, and not due to a decline in exports. Despite the coincident rise in oil prices and the Canadian exchange rate, we find no evidence of Dutch disease as a consequence of QE, since GDP in almost all industries shows gains.

\section{Robustness}

The qualitative findings documented in section 3.2 are robust to changes in the number of factors between four and ten, relaxing the coefficient restriction in the VAR from equation (2), a log-difference transformation of the $\mathrm{QE}$ variable, or minor changes in the way the counterfactual path for the QE variable is calculated.

In this section, we first provide an alternative specification that includes a combination of changes. Specifically, we include eight U.S. factors and six Canadian factors (instead of six and four, respectively), and remove any coefficient restriction in equation (2), so that Canadian factors can influence movements in U.S. factors and policy variables. Furthermore, we take the log difference of the QE variable instead of the level difference, as in the benchmark case, and consider a counterfactual path where the QE variable grows according to a linear and quadratic time trend. The results are shown in Figure 7.

Although the point estimates of the quantitative effect of $\mathrm{QE}$ on the two economies have changed slightly, qualitatively the story remains the same. Namely, the effect of QE on the U.S. domestic economy is expansionary, and brought forth by a reduction in long-term yields. The spillover effect on Canada is also stimulative, and of the same order of magnitude as the domestic effect. The international transmission of QE occurs through the financial channel with lower spreads and higher asset prices, as net trade provides a source of leakage for Canada.

Second, we ask whether the transmission of U.S. monetary easing occurs through different channels for the case of QE than conventional monetary policy. To this end,

we estimate Cholesky-ordered impulse-response functions for a 100 bps reduction in the effective federal funds rate in our benchmark FAVAR specification with pre-crisis data, to avoid including the period of the zero lower bound, which is uninformative for shocks to the effective funds rate. The results are shown in Figure 8. Note that the exercise so far 
has been to generate the difference between two conditional forecasts - one reflecting the presence of QE, and the other without. As such, they cannot be directly compared with the impulse responses shown in Figure 8. Our purpose here is to check for the direction of responses to determine whether there is a consistent story regarding the transmission channel of U.S. monetary easing.

Following a reduction in the federal funds rate, U.S. GDP increases, while the tradeweighted nominal exchange rate depreciates. ${ }^{13}$ The transmission of the U.S. monetary easing to Canada again occurs through financial channels, as the short-term Canadian rate declines and Canadian asset prices (TSX index) increase. The trade channel, however, provides a source of leakage to Canada, as the Canadian nominal exchange rate vis-à-vis the United States appreciates and Canadian net exports fall. This result is consistent with Kim [2001], who explores the transmission of conventional U.S. monetary policy shocks to Canada using a small-scale structural VAR and finds that the financial channel is the main source of spillovers.

\section{Conclusion}

In the aftermath of the global financial crisis, the U.S. Federal Reserve provided unprecedented monetary stimulus to an ailing domestic economy by reducing long-term interest rates through quantitative easing, or large-scale purchases of long-term assets, when their conventional short-term policy rate became ineffective at the zero lower bound. Although the domestic effect of QE is largely understood to be expansionary, its international spillover effect is complicated, from a theoretical standpoint, by the countervailing effects of expenditure switching, income absorption and global financial integration.

In this paper, we empirically assess the international transmission of the Fed's QE program by looking at spillovers to Canada. We estimate the effect of QE on the Canadian economy in a two-country FAVAR framework by comparing conditional forecasts of two scenarios - one where the Fed's long-term asset holdings follow its observed path, and a counterfactual, where they do not increase in response to the great recession.

We find that the implementation of QE increases U.S. GDP by about 2.3 percent, and Canadian GDP by 2.2 percent through reductions in long-term spreads for both countries. The positive spillover of QE to Canada occurs mainly from the financial channel through synchronized asset prices and yield spreads across the two countries, while the trade channel provides leakage through a higher Canadian exchange rate and reduced net exports. However, we find evidence that these leakages are a consequence of a stronger Canadian demand for imports, rather than a reduction in exports. Moreover, despite the joint rise in oil prices and the Canadian exchange rate, we find no evidence of Dutch disease as a consequence of QE, since GDP in almost all industries shows gains.

Our results are robust to reasonable changes in our empirical framework and counterfactual assumptions, and are consistent with the existing literature on the effect of $\mathrm{QE}$

\footnotetext{
${ }^{13}$ Note, however, that U.S. prices decline, albeit statistically insignificantly, suggesting that considering a FAVAR set-up for our specific sample does not rid us completely of the price puzzle first documented by Sims [1992].
} 
on the U.S. domestic economy and global financial markets, as well as the literature on the international transmission of conventional U.S. monetary stimulus.

\section{References}

Jushan Bai and Serena Ng. Determining the number of factors in approximate factor models. Econometrica, 70(1):191-221, 2002.

Michael D. Bauer and Christopher J. Neely. International channels of the Feds unconventional monetary policy. Technical report, 2012.

Christiane Baumeister and Luca Benati. Unconventional monetary policy and the great recession: Estimating the macroeconomic effects of a spread compression at the zero lower bound. International Journal of Central Banking, 9(2):165-212, June 2013.

Ben Bernanke, Jean Boivin, and Piotr S. Eliasz. Measuring the effects of monetary policy: A factor-augmented vector autoregressive (FAVAR) approach. Quarterly Journal of Economics, 120(1):387-422, January 2005.

Ben S. Bernanke. Monetary Policy since the Onset of the Crisis: a speech at the Federal Reserve Bank of Kansas City Economic Symposium, Jackson Hole, Wyoming, August 31, 2012. (645), August 2012. URL http://ideas.repec.org/p/fip/fedgsq/645. html.

Jean Boivin and Marc P. Giannoni. Global forces and monetary policy effectiveness. In International Dimensions of Monetary Policy, NBER Chapters, pages 429-478. National Bureau of Economic Research, Inc, July 2007. URL http://ideas.repec. org/h/nbr/nberch/0515.html.

Valery Charnavoki and Juan J. Dolado. The Effects of Global Shocks on Small Commodity-Exporting Economies: Lessons from Canada. American Economic Journal: Macroeconomics, 6(2):207-37, April 2014. URL http://ideas.repec.org/a/ aea/aejmac/v6y2014i2p207-37.html.

Hess Chung, JeanPhilippe Laforte, David Reifschneider, and John C. Williams. Have We Underestimated the Likelihood and Severity of Zero Lower Bound Events? Journal of Money, Credit and Banking, 44:47-82, 02 2012. URL http://ideas.repec.org/a/ $\mathrm{mcb} / \mathrm{jmoncb} / \mathrm{v} 44 \mathrm{y} 2012 \mathrm{ip} 47-82 . \mathrm{html}$.

Jose Dorich, Michael K. Johnston, Rhys R. Mendes, Stephen Murchison, and Yang Zhang. ToTEM II: An Updated Version of the Bank of Canada's Quarterly Projection Model. Technical report, 2013.

Christine Fay and Toni Gravelle. The Market Impact of Forward-Looking Policy Statements: Transparency vs. Predictability. Bank of Canada Review, 2008(Winter):27-36, 2008. URL http://ideas.repec.org/a/bca/bcarev/ v2009y2009iwinter08-09p27-36 . html. 
Marcel Fratzscher, Marco Lo Duca, and Roland Straub. On the international spillovers of US quantitative easing. Working Paper Series 1557, European Central Bank, June 2013. URL http://ideas.repec.org/p/ecb/ecbwps/20131557.html.

Joseph Gagnon, Matthew Raskin, Julie Remache, and Brian Sack. Large-scale asset purchases by the Federal Reserve: did they work? Economic Policy Review, (May): 41-59, 2011. URL http://ideas.repec.org/a/fip/fednep/y2011imayp41-59nv. 17no.1.html.

Leonardo Gambacorta, Boris Hofmann, and Gert Peersman. The Effectiveness of Unconventional Monetary Policy at the Zero Lower Bound: A Cross-Country Analysis. BIS Working Papers 384, Bank for International Settlements, August 2012. URL http://ideas.repec.org/p/bis/biswps/384.html.

Michael A. S. Joyce, Ana Lasaosa, Ibrahim Stevens, and Matthew Tong. The Financial Market Impact of Quantitative Easing in the United Kingdom. International Journal of Central Banking, 7(3):113-161, September 2011. URL http://ideas.repec.org/ a/ijc/ijcjou/y2011q3a5.html.

George Kapetanios, Haroon Mumtaz, Ibrahim Stevens, and Konstantinos Theodoridis. Assessing the economywide effects of quantitative easing. Economic Journal, 122(564): F316-F347, November 2012.

Irfan Akbar Kazi, Hakimzadi Wagan, and Farhan Akbar. The changing international transmission of U.S. monetary policy shocks: Is there evidence of contagion effect on OECD countries. Economic Modelling, 30(C):90-116, 2013. URL http://ideas . repec.org/a/eee/ecmode/v30y2013icp90-116.html.

Soyoung Kim. International transmission of U.S. monetary policy shocks: Evidence from VAR's. Journal of Monetary Economics, 48(2):339-372, October 2001. URL http://ideas.repec.org/a/eee/moneco/v48y2001i2p339-372.html.

Sharon Kozicki, Eric Santor, and Lena Suchanek. Unconventional Monetary Policy: The International Experience with Central Bank Asset Purchases. Bank of Canada Review, 2011(Spring):13-25, 2011. URL http://ideas.repec.org/a/bca/bcarev/ v2011y2011ispring11p13-25.html.

Arvind Krishnamurthy and Annette Vissing-Jorgensen. The Effects of Quantitative Easing on Interest Rates: Channels and Implications for Policy. NBER Working Papers 17555, National Bureau of Economic Research, Inc, October 2011. URL http://ideas.repec.org/p/nbr/nberwo/17555.html.

Michele Lenza, Huw Pill, and Lucrezia Reichlin. Monetary policy in exceptional times. Economic Policy, 25:295-339, 04 2010. URL http://ideas.repec.org/a/ bla/ecpoli/v25y2010ip295-339.html. 
Christopher J. Neely. The large scale asset purchases had large international effects. Technical report, 2010.

Kenneth Rogoff. Dornbusch's Overshooting Model After Twenty-Five Years. IMF Working Papers 02/39, International Monetary Fund, February 2002. URL http: //ideas.repec.org/p/imf/imfwpa/02-39.html.

Heike Schenkelberg and Sebastian Watzka. Real effects of quantitative easing at the zero lower bound: Structural VAR-based evidence from Japan. Journal of International Money and Finance, 33(C):327-357, 2013. URL http://ideas.repec.org/a/eee/ jimfin/v33y2013icp327-357.html.

Christopher A. Sims. Interpreting the macroeconomic time series facts: The effects of monetary policy. European Economic Review, 36(5):975-1000, June 1992. URL http://ideas.repec.org/a/eee/eecrev/v36y1992i5p975-1000.html.

Michael Woodford. Methods of policy accommodation at the interest-rate lower bound. Proceedings - Economic Policy Symposium - Jackson Hole, pages 185-288, 2012. URL http://ideas.repec.org/a/fip/fedkpr/y2012p185-288.html.

Lorie Zorn, Carolyn Wilkins, and Walter Engert. Bank of Canada Liquidity Actions in Response to the Financial Market Turmoil. Bank of Canada Review, 2009(Autumn):7-26, 2009. URL http://ideas.repec.org/a/bca/bcarev/ v2009y2009iautumn09p7-26.html. 
Table 1: Goods trade between Canada and the United States (2000-2007 averages)

\begin{tabular}{lccccc}
\hline & \multicolumn{3}{c}{ \% of country's total exports or imports } \\
\cline { 2 - 3 } & $\begin{array}{c}\text { Can exports } \\
\text { to U.S. }\end{array}$ & $\begin{array}{c}\text { U.S. imports } \\
\text { from Can }\end{array}$ & & $\begin{array}{c}\text { Can imports } \\
\text { from U.S. }\end{array}$ & $\begin{array}{c}\text { U.S. exports } \\
\text { to Can }\end{array}$ \\
\cline { 2 - 3 } \cline { 5 - 6 } All goods & 83.9 & 17.3 & & 58.9 & 22.7 \\
Agriculture & 45.1 & 19.2 & & 64.1 & 13.5 \\
Forestry & 84.9 & 55.1 & & 71.7 & 33.6 \\
Oil and gas & 98.9 & 22.8 & & 20.6 & 22.3 \\
Mining (ex. oil and gas) & 35.4 & 25.6 & & 53.4 & 29.5 \\
Consumer goods & 77.7 & 14.7 & & 50.0 & 25.0 \\
Chemicals & 85.1 & 16.5 & & 69.4 & 20.4 \\
Metals and minerals & 80.6 & 20.3 & & 61.0 & 32.2 \\
Machinery & 77.7 & 11.9 & & 61.8 & 22.5 \\
Electronics & 76.4 & 5.0 & & 46.2 & 15.7 \\
Autos & 97.3 & 29.9 & & 77.3 & 56.0 \\
Other transportation & 71.9 & 23.1 & & 56.9 & 8.7 \\
Other goods & 82.6 & 2.5 & & 44.2 & 15.0 \\
\hline
\end{tabular}

Notes: Calculated based on nominal annual series in CAD (industry breakdown of Canadian exports and imports) and USD (all other values). Percentages of total goods exports may not sum to 100 due to some omitted categories.

Sources: IMF Direction of Trade Statistics, WDI, U.S. Census Bureau and Industry Canada 
Table 2: U.S. share of total Canadian international investment position

\begin{tabular}{lcc}
\hline & $2000-2007$ & $2008-2013$ \\
\hline Total assets & 47.4 & 46.3 \\
Canadian direct investment abroad & 45.8 & 41.4 \\
Canadian portfolio investment & 54.1 & 51.0 \\
Foreign debt securities & 63.8 & 68.0 \\
Foreign equity and investment fund shares & 50.5 & 42.5 \\
Total liabilities & 58.9 & 57.7 \\
Foreign direct investment & 63.4 & 52.6 \\
Foreign portfolio investment & 60.8 & 62.1 \\
Canadian debt securities & 55.9 & 59.6 \\
Canadian equity and investment fund shares & 80.8 & 71.2 \\
\hline
\end{tabular}

Note: Calculated using quarterly nominal data in CAD.

Source: Statistics Canada (table 376-0142).

Table 3: Cross-correlations of Canadian variables with U.S. counterparts (1983Q12007Q4)

\begin{tabular}{|c|c|c|c|c|c|c|c|}
\hline & \multicolumn{7}{|c|}{ Cross-correlations with (leads/lags of) US variables } \\
\hline & \multirow[b]{2}{*}{-4} & \multirow[b]{2}{*}{-2} & \multirow[b]{2}{*}{-1} & \multirow[b]{2}{*}{0} & \multicolumn{3}{|c|}{ leads } \\
\hline & & & & & 1 & 2 & 4 \\
\hline \multicolumn{8}{|l|}{ Real economy } \\
\hline GDP & 0.352 & 0.640 & 0.721 & 0.737 & 0.641 & 0.481 & 0.095 \\
\hline Consumption & 0.339 & 0.451 & 0.498 & 0.532 & 0.466 & 0.354 & 0.108 \\
\hline Investment & 0.173 & 0.236 & 0.304 & 0.345 & 0.391 & 0.366 & 0.110 \\
\hline \multicolumn{8}{|l|}{ Financial markets } \\
\hline TSX/ S\&P 500 & 0.184 & 0.440 & 0.549 & 0.724 & 0.621 & 0.405 & 0.108 \\
\hline 3-m Treasury yields & 0.364 & 0.694 & 0.795 & 0.800 & 0.660 & 0.481 & 0.135 \\
\hline 10-y Spreads & 0.058 & 0.457 & 0.639 & 0.773 & 0.697 & 0.484 & 0.051 \\
\hline
\end{tabular}

Notes: All variables except yields and spreads are in logarithms. All variables are filtered with HP-filter $(\lambda=1600)$.

Sources: Statistics Canada, Bank of Canada, U.S. Bureau of Economic Analysis, Wall Street Journal and Federal Reserve Board 
Figure 1: Central bank assets, policy rate and long-term spreads (2006Q1-2013Q4) U.S.

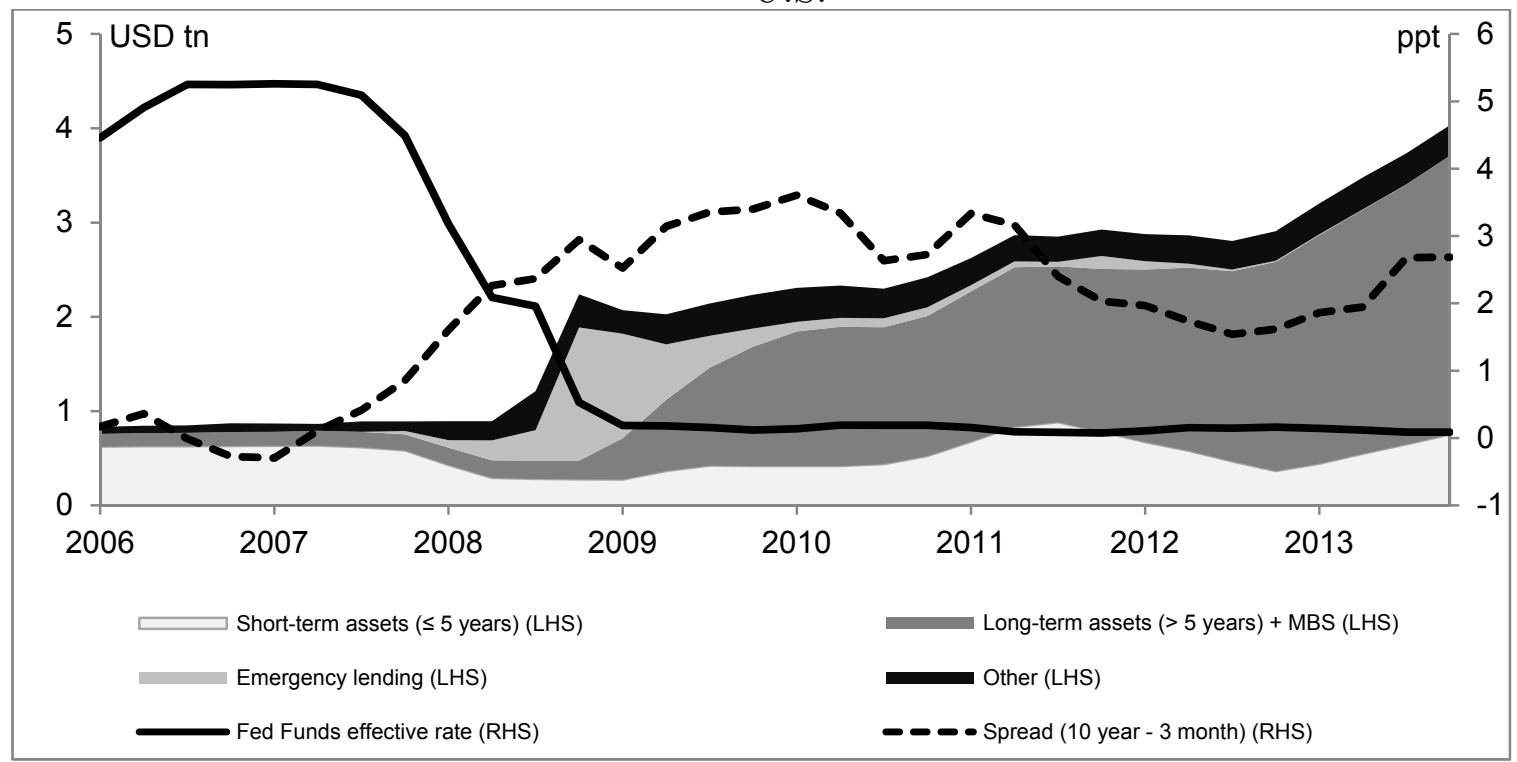

Canada

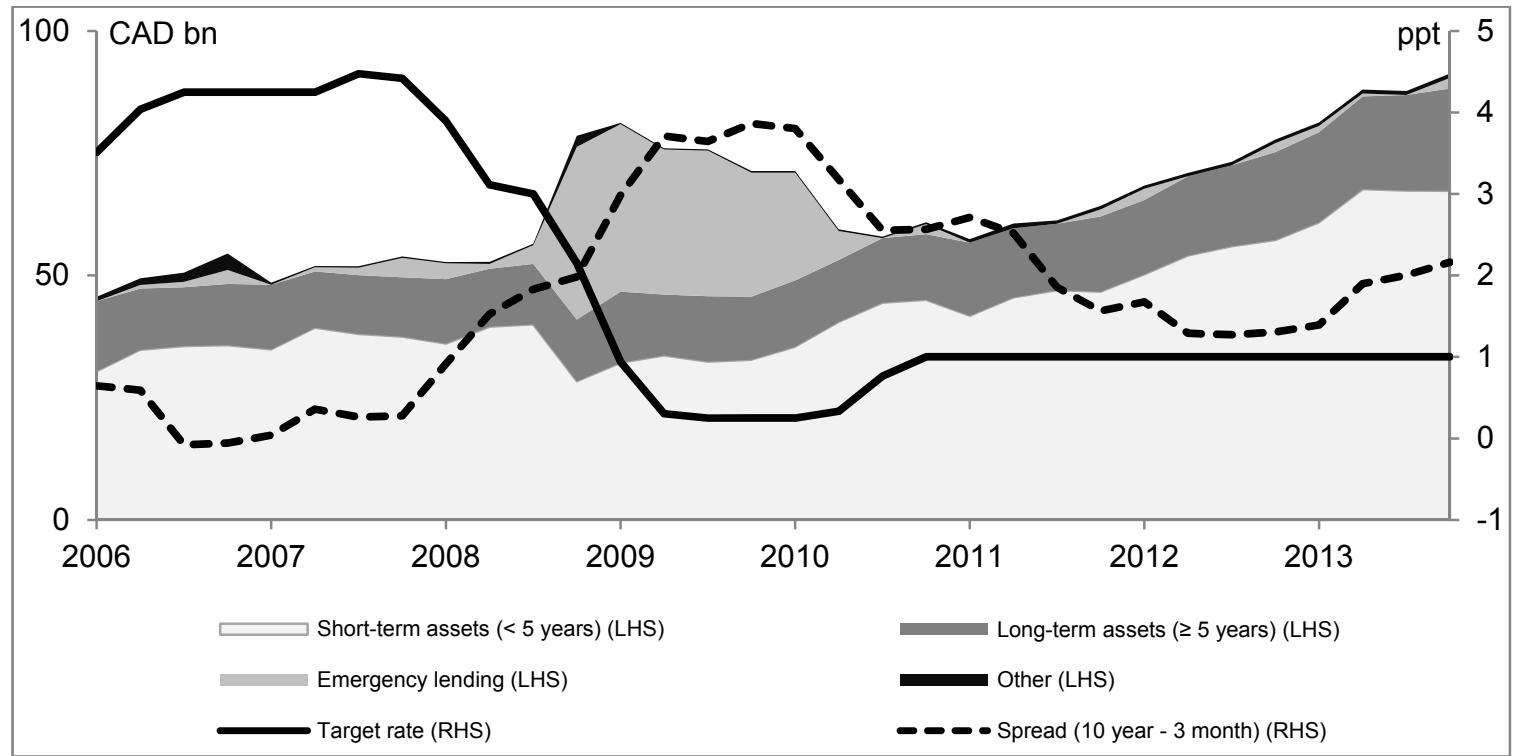

Notes: The top (U.S.) chart reports quarterly averages. The bottom (Canada) chart reports end-of-period data or balance-sheet assets, and quarterly averages for remaining series.

Sources: U.S. Federal Reserve Board, U.S. Treasury and Bank of Canada 
Figure 2: Impact of QE on the U.S. economy
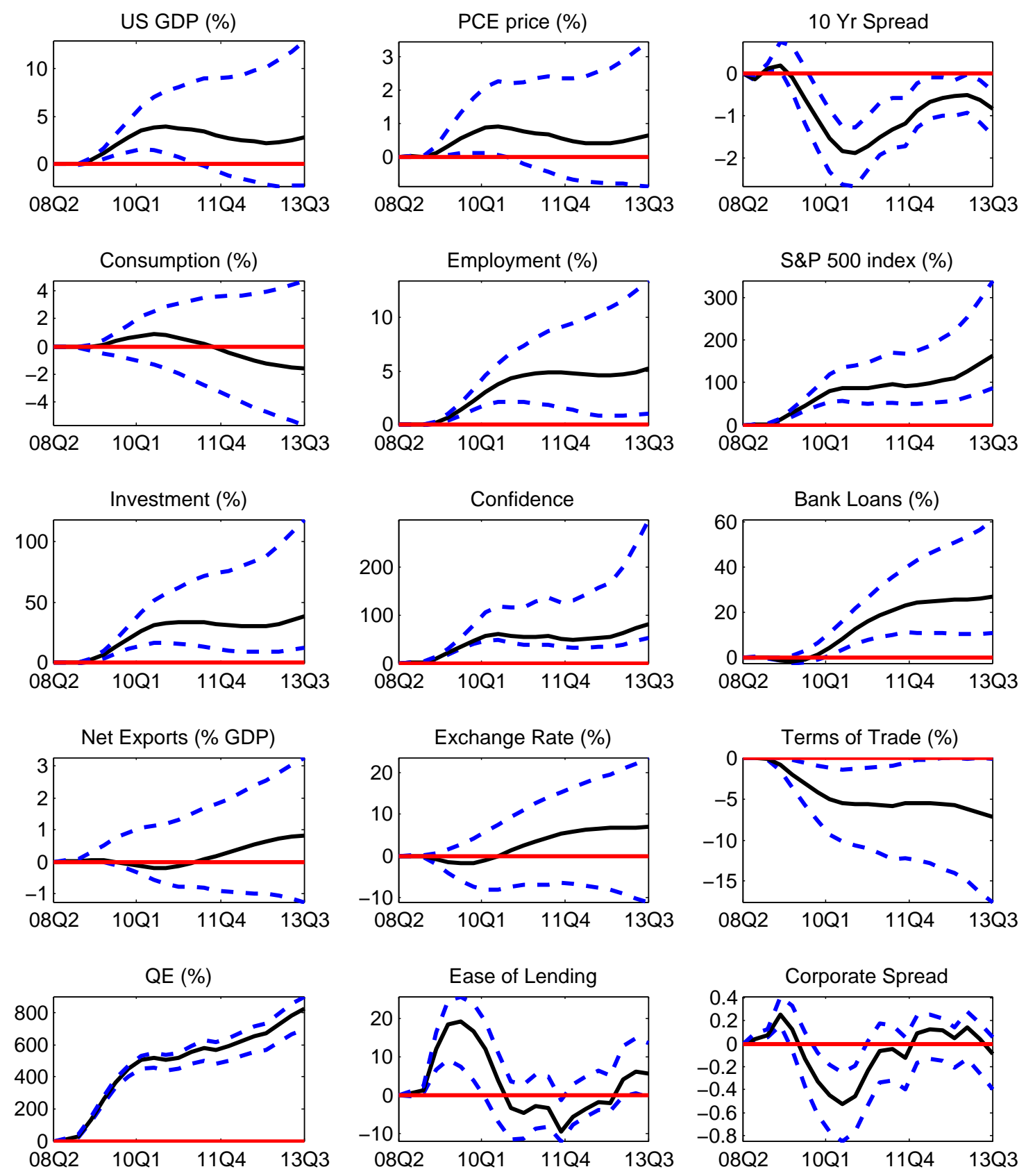

Notes: Difference between the policy scenario and the counterfactual scenario without QE. Point estimate of counterfactual difference along with $68 \%$ confidence intervals. Results in percentage difference from the no-QE scenario when noted, and in level differences otherwise. 
Figure 3: Impact of QE on the Canadian economy
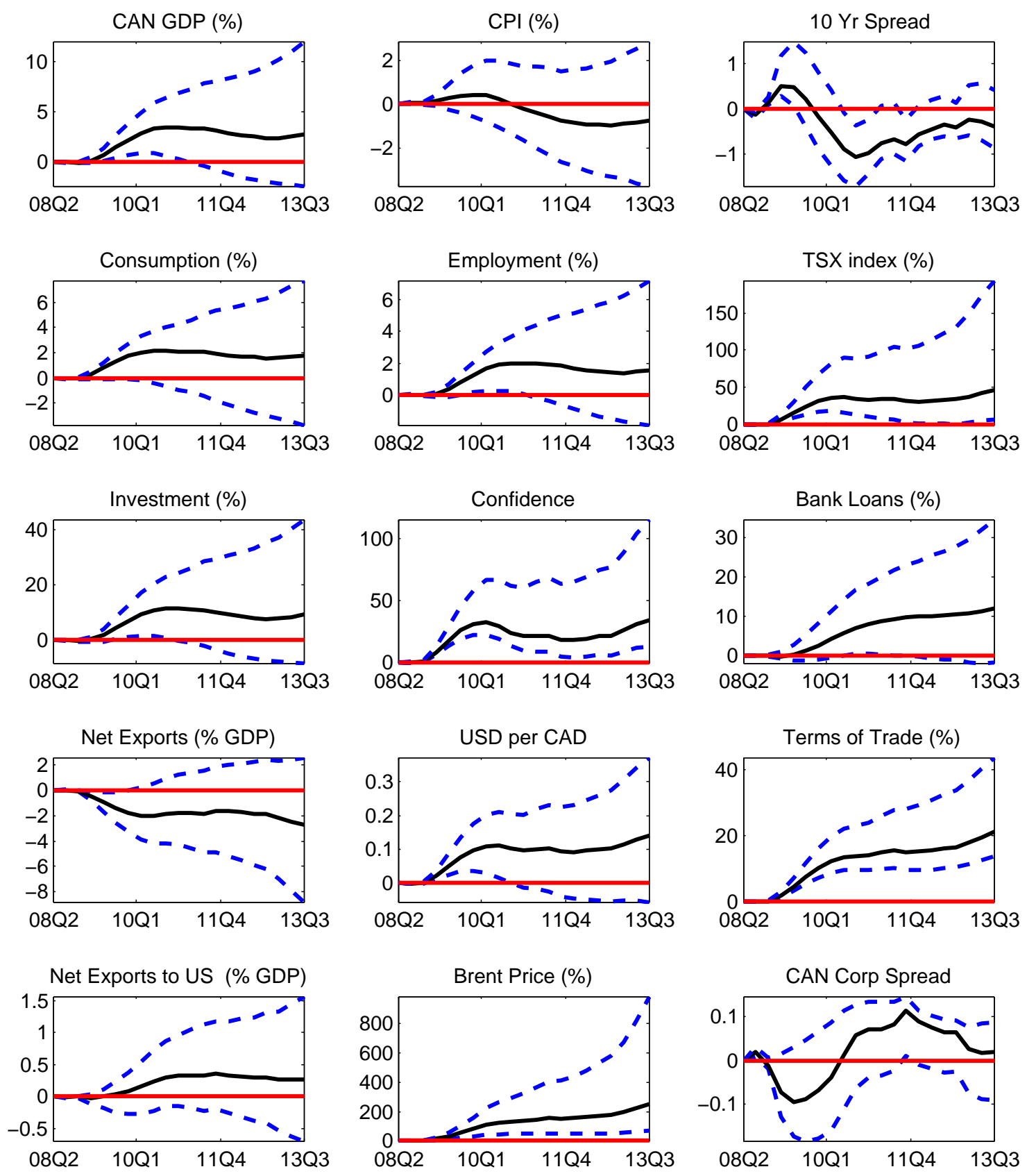

Notes: Difference between the policy scenario and the counterfactual scenario without QE. Point estimate of counterfactual difference along with $68 \%$ confidence intervals. Results in percentage difference from the no-QE scenario when noted, and in level differences otherwise. 
Figure 4: Impact of QE on Canadian global trade by product
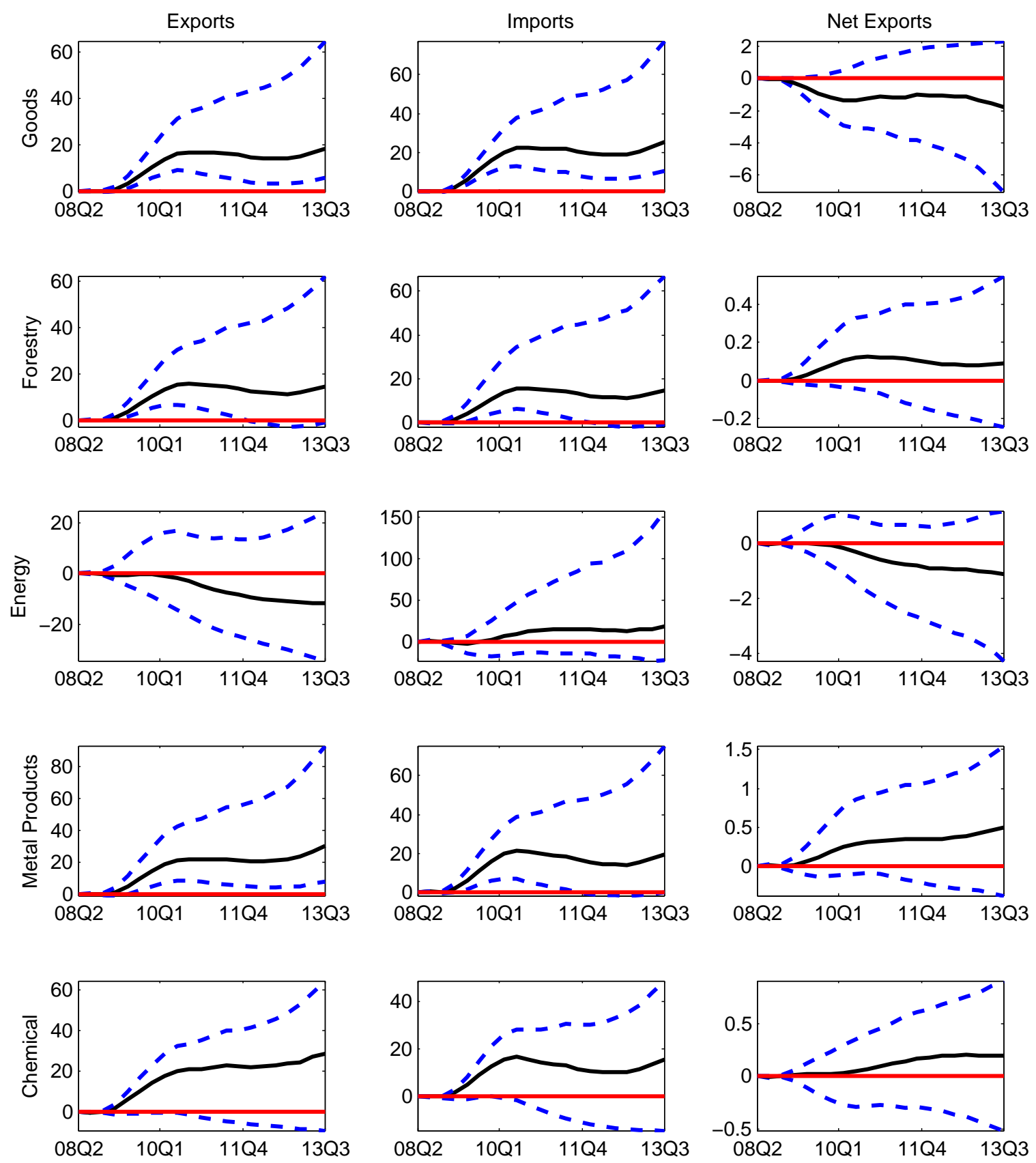

Notes: Difference between the policy scenario and the counterfactual scenario without QE. Point estimate of counterfactual difference along with $68 \%$ confidence intervals. Results in percentage difference from the no-QE scenario when noted, and in level differences otherwise. 
Figure 5: Impact of QE on Canadian global trade by product
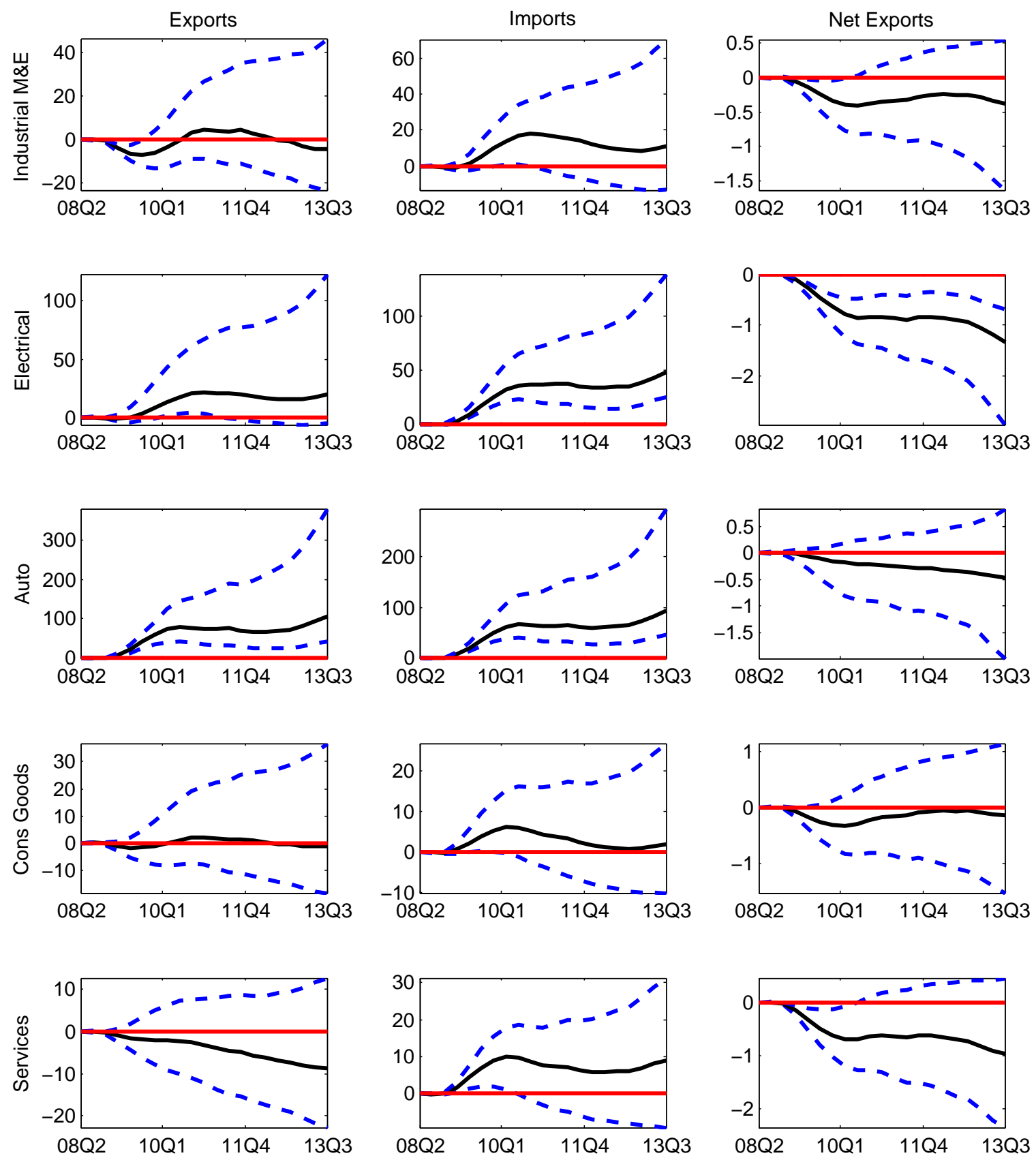

Notes: Difference between the policy scenario and the counterfactual scenario without QE. Point estimate of counterfactual difference along with $68 \%$ confidence intervals. Results in percentage difference from the no-QE scenario when noted, and in level differences otherwise. 
Figure 6: Impact of QE on the Canadian GDP by industry
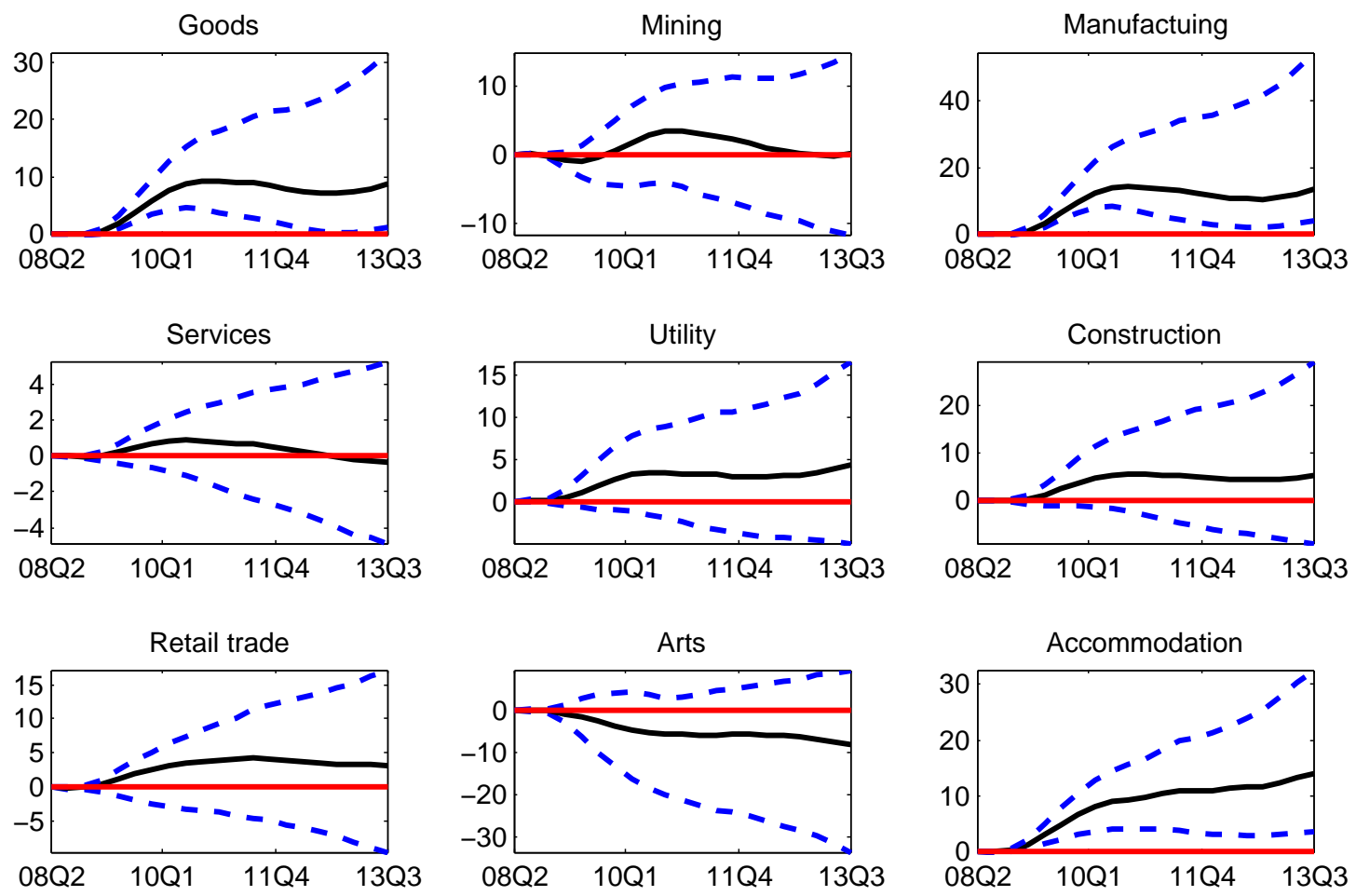

Notes: Difference between the policy scenario and the counterfactual scenario without QE. Point estimate of counterfactual difference along with $68 \%$ confidence intervals. Results in percentage difference from the no-QE scenario when noted, and in level differences otherwise. 
Figure 7: Impact of QE on the U.S. and Canadian economy - alternative case Panel A: U.S.
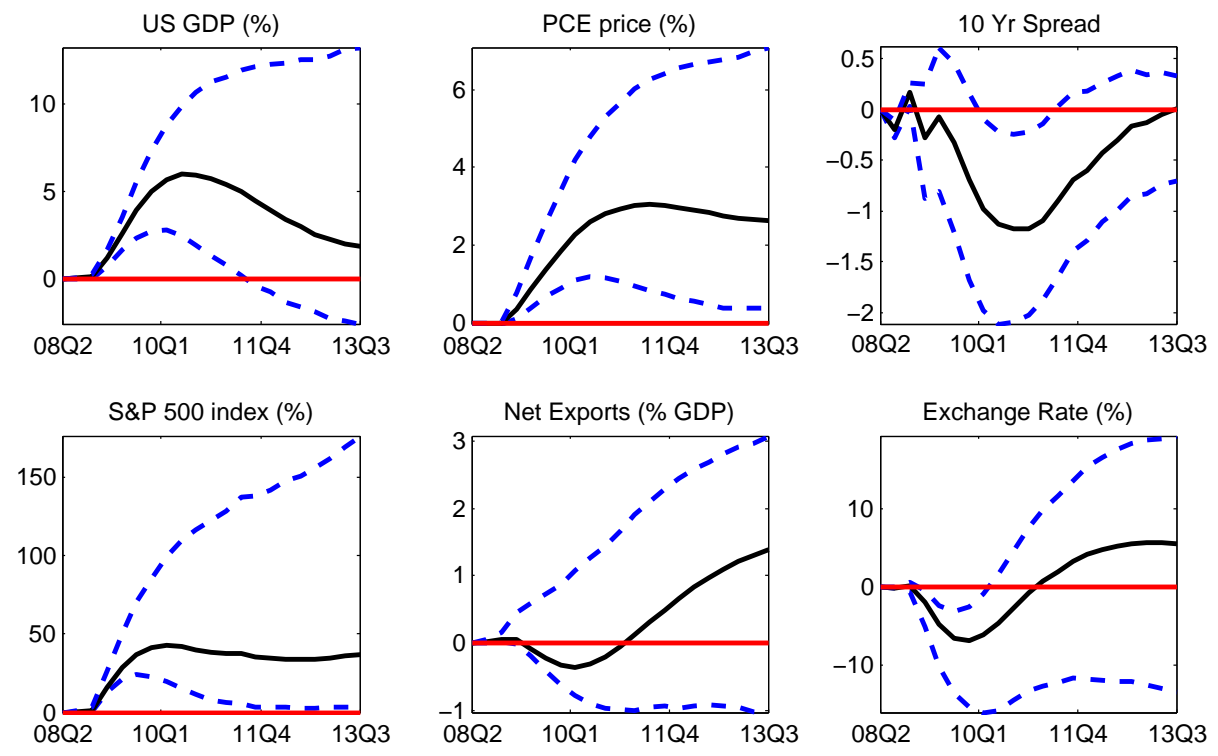

Panel B: Canada
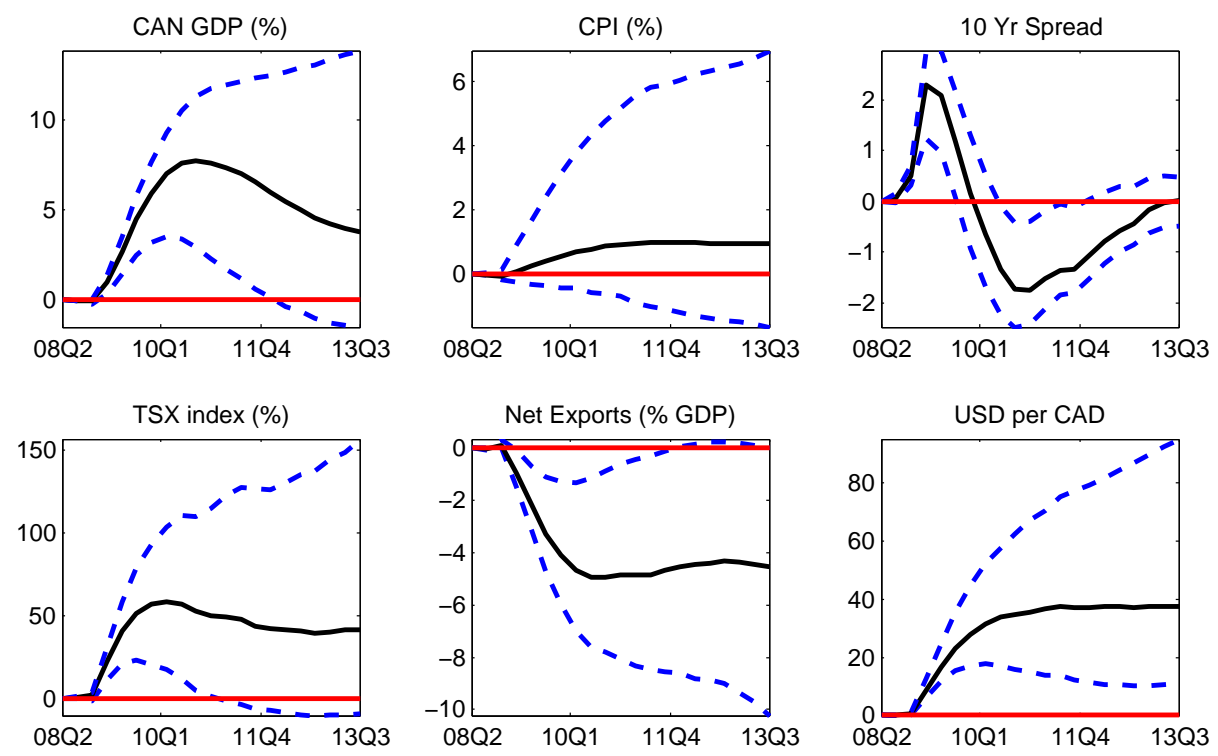

Notes: Difference between the policy scenario and the counterfactual scenario without QE. Point estimate of counterfactual difference along with $68 \%$ confidence intervals. Results in percentage difference from the no-QE scenario when noted, and in level differences otherwise. 
Figure 8: Impulse responses of a 100 bps reduction in the effective federal funds rate Panel A: U.S.
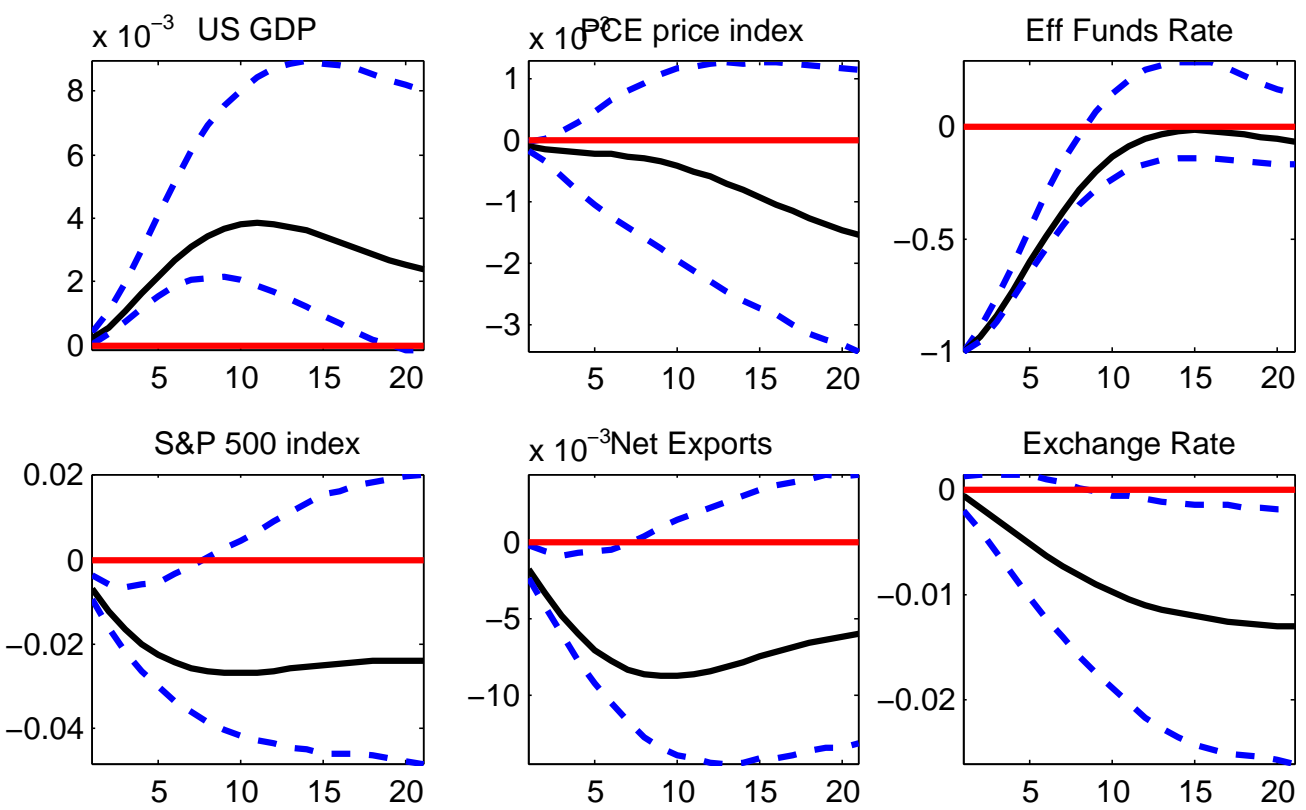

Panel B: Canada
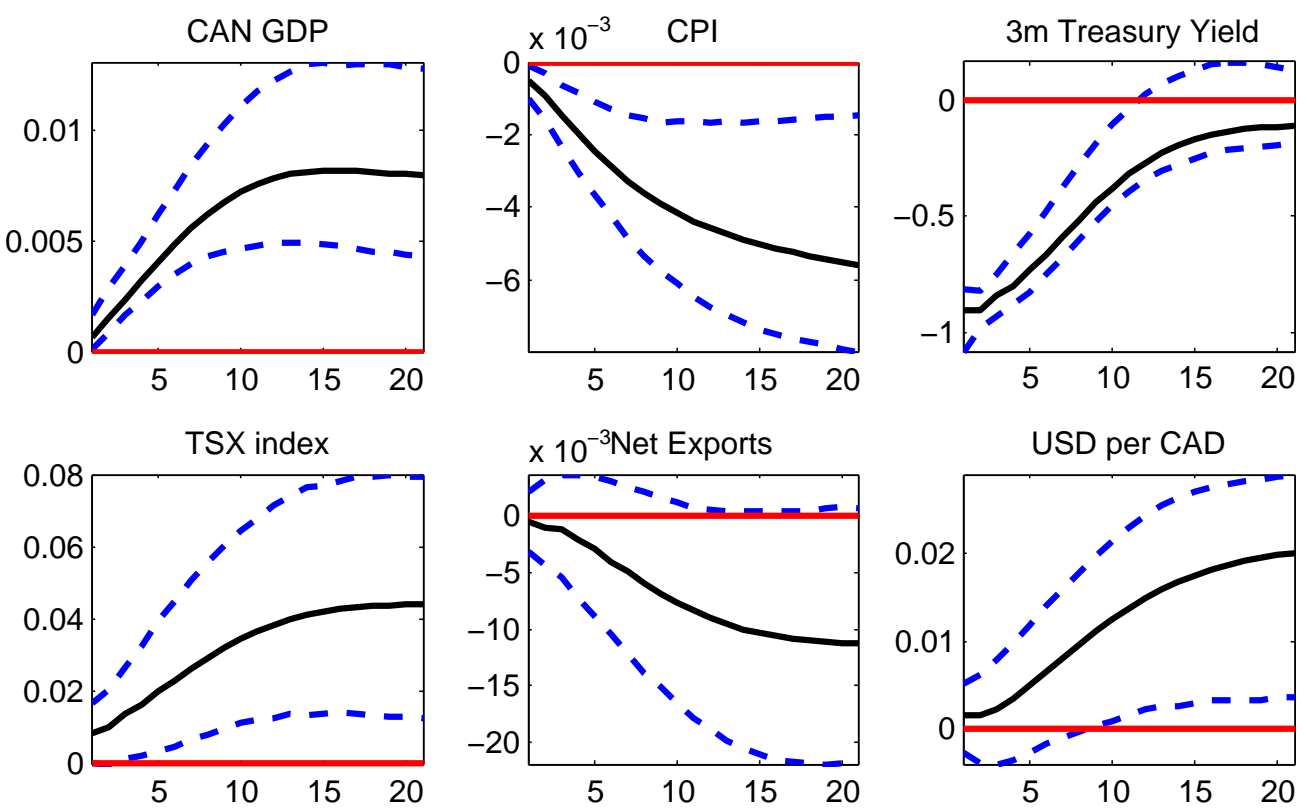

Notes: Impulse-response functions along with $68 \%$ confidence bands. Data span from 1983Q1 through 2008Q2. 


\section{Appendix: Data Description}

Format is: series number, series mnemonic, transformation code, series description, source, and the degree to which factors included in the baseline specification explain the variation of the variable (R-squared). All data available from 1983Q1-2013Q3. The transformation codes are: 1 - no transformation; 2 - first difference; 4 - logarithm; 5 first difference of logarithm. The majority of series were taken from Haver Analytics.

Sources: FRB - Federal Reserve Board, UST - U.S. Treasury, BEA - Bureau of Economic Analysis, JPM - JP Morgan, BLS - Bureau of Labor Statistics, ISM Institute for Supply Management, CB - Census Bureau, S\&P - Standard and Poor's, FRB-C - Federal Reserve Bank of Chicago, GZ - Gilchrist and Zakrajsek 2012, BoC - Bank of Canada, Statcan - Statistics Canada, TSX - Toronto Stock Exchange, IMF - International Monetary Fund, CMHC - Canada Mortgage and Housing Corporation, BIS - Bank for International Settlements

\begin{tabular}{|c|c|c|c|c|c|}
\hline \multicolumn{6}{|c|}{ US Variables } \\
\hline \multicolumn{6}{|c|}{ Monetary policy } \\
\hline 1 & USEffFedFundsRate & 1 & Federal Funds [Effective] Rate (\% p.a.) & FRB & 1.00 \\
\hline 2 & QE2 & 2 & $\begin{array}{l}\text { Fed Res Banks: UST Security Holdings: Over } 5 \text { Yrs + Mortgage- } \\
\text { Backed Securities Held Outright (EOP, Mil.\$) }\end{array}$ & FRB & 1.00 \\
\hline \multicolumn{6}{|c|}{ National income and products accounts } \\
\hline 3 & USrGDP & 5 & Real Gross Domestic Product (SAAR, Bil.Chn.2009\$) & BEA & 0.69 \\
\hline 4 & $\mathrm{USrC}$ & 5 & Real Personal Consumption Expenditures (SAAR, Bil.Chn.2009\$) & BEA & 0.53 \\
\hline 5 & USrI & 5 & Real Gross Private Domestic Investment (SAAR, Bil.Chn.2009\$) & $\mathrm{BEA}$ & 0.62 \\
\hline 6 & USrExports & 5 & Real Exports of Goods \& Services (SAAR, Bil.Chn.2009\$) & BEA & 0.52 \\
\hline 7 & USrImports & 5 & Real Imports of Goods \& Services (SAAR, Bil.Chn.2009\$) & BEA & 0.66 \\
\hline 8 & USrG & 5 & $\begin{array}{l}\text { Real Government Consumption Expenditures \& Gross Invest- } \\
\text { ment(SAAR, Bil.Chn.2009\$) }\end{array}$ & BEA & 0.34 \\
\hline 9 & USnExports & 5 & Exports of Goods and Services (SAAR, Bil.\$) & BEA & 0.69 \\
\hline 10 & USnExportsReceipts & 5 & Exports: Income Receipts from ROW (SAAR, Bil.\$) & BEA & 0.61 \\
\hline 11 & USnImports & 5 & Imports of Goods and Services (SAAR, Bil.\$) & BEA & 0.8 \\
\hline 12 & USnImportsPayments & 5 & Imports: Income Payments to ROW (SAAR, Bil.\$) & BEA & 0.42 \\
\hline 13 & USnGDP & 5 & Gross Domestic Product (SAAR, Bil.\$) & BEA & 0.75 \\
\hline \multicolumn{6}{|c|}{ Real output and income } \\
\hline 14 & USIPFinalNonind & 5 & $\begin{array}{l}\text { Industrial Production: Final Products and Nonindustrial Supplies } \\
\text { (SA, 2007=100) }\end{array}$ & FRB & 0.88 \\
\hline 15 & USIPFinal & 5 & Industrial Production: Final Products (SA, 2007=100) & FRB & 0.84 \\
\hline 16 & USIPCons & 5 & Industrial Production: Consumer Goods (SA, 2007=100) & FRB & 0.62 \\
\hline 17 & USIPConsDur & 5 & Industrial Production: Durable Consumer Goods (SA, 2007=100) & FRB & 0.63 \\
\hline 18 & USIPConsNonDur & 5 & $\begin{array}{l}\text { Industrial Production: Nondurable Consumer Goods (SA, } \\
2007=100)\end{array}$ & FRB & 0.23 \\
\hline 19 & USIPBusi & 5 & Industrial Production: Business Equipment (SA, 2007=100) & FRB & 0.81 \\
\hline 20 & USIPMat & 5 & Industrial Production: Materials (SA, 2007=100) & FRB & 0.86 \\
\hline 21 & USIPMatDur & 5 & Industrial Production: Durable Goods Materials (SA, 2007=100) & FRB & 0.88 \\
\hline 22 & USIPMatNonDur & 5 & $\begin{array}{l}\text { Industrial Production: Nondurable Goods Materials (SA, } \\
2007=100)\end{array}$ & FRB & 0.61 \\
\hline 23 & USIPMan & 5 & Industrial Production: Manufacturing [NAICS] (SA, 2007=100) & FRB & 0.91 \\
\hline 24 & USIPMin & 5 & Industrial Production: Mining $(\mathrm{SA}, 2007=100)$ & FRB & 0.27 \\
\hline 25 & USIPUtl & 5 & Industrial Production: Electric and Gas Utilities (SA, 2007 $=100$ ) & FRB & 0.06 \\
\hline 26 & USIPindex & 5 & Industrial Production Index $(\mathrm{SA}, 2007=100)$ & FRB & 0.91 \\
\hline \multicolumn{6}{|c|}{ Employment } \\
\hline 27 & USLabourForce & 5 & Civilian Labor Force: 16 yr + (SA, Thous) & BLS & 0.31 \\
\hline 28 & USUnempRate & 5 & Civilian Unemployment Rate: 16 yr + (SA, \%) & BLS & 0.83 \\
\hline 29 & USUnempLess $5 \mathrm{w}$ & 5 & Civilians Unemployed for Less Than 5 Weeks (SA, Thous.) & BLS & 0.35 \\
\hline 30 & USUnemp5to14w & 5 & Civilians Unemployed for 5-14 Weeks (SA, Thous.) & BLS & 0.61 \\
\hline
\end{tabular}




$\begin{array}{ll}31 & \text { USUnemp15to26w } \\ 32 & \text { USEmpNonfarm } \\ 33 & \text { USEmpIndustry } \\ 34 & \text { USEmpGoodsIndustry } \\ 35 & \text { USEmpLog } \\ 36 & \text { USEmpMin } \\ 37 & \text { USEmpUtl } \\ 38 & \text { USEmpCon } \\ 39 & \text { USEmpMan } \\ 40 & \text { USEmpManDur } \\ 41 & \text { USEmpManNonDur } \\ 42 & \text { USEmpSvc } \\ 43 & \text { USEmpTrn } \\ 44 & \text { USEmpRet } \\ 45 & \text { USEmpWht } \\ 46 & \text { USEmpFin } \\ 47 & \text { USEmpInf } \\ 48 & \text { USEmpGov } \\ 49 & \text { USEmpIndex } \\ \text { Housing starts and sales } \\ 50 & \text { USHousingStarts } \\ 51 & \text { USHousingStartsNE } \\ 52 & \text { USHousingStartsMidwest } \\ 53 & \text { USHousingStartsSouth } \\ 54 & \text { USHousingStartsWest } \\ 55 & \text { USNewHousingPermits }\end{array}$

ISM (NAPM) manufacturing survey

\begin{tabular}{|c|c|}
\hline & \\
\hline 56 & USInventories \\
\hline 57 & USNewOrders \\
\hline 58 & USDeliveries \\
\hline Stc & prices \\
\hline 59 & USSP500index \\
\hline 60 & USSP500IndusIndex \\
\hline Ex & ange rates \\
\hline 61 & USNEER \\
\hline 62 & CHFzUSD \\
\hline 63 & JPYzUSD \\
\hline 64 & USDzGBP \\
\hline Int & est rates \\
\hline 65 & US3mYield \\
\hline 66 & US6mYield \\
\hline 67 & US1yYield \\
\hline 68 & US5yYield \\
\hline 69 & US10yYield \\
\hline 70 & USAAAyield \\
\hline 71 & USBAAyield \\
\hline 72 & ShadowRate \\
\hline 73 & US6mSpread \\
\hline 74 & US1ySpread \\
\hline 75 & US5ySpread \\
\hline 76 & US10ySpread \\
\hline 77 & USCorporateSpread \\
\hline $\mathrm{Ba}$ & nce of payments \\
\hline 78 & USCurrAcctBal \\
\hline 79 & USKInflows \\
\hline 80 & USKOutflows \\
\hline Pr & indexes \\
\hline 81 & USGDPprices \\
\hline 82 & USPCEprices \\
\hline
\end{tabular}

Civilians Unemployed for 15-26 Weeks (SA, Thous.)

All Employees: Total Nonfarm (SA, Thous)

All Employees: Total Private Industries (SA, Thous)

All Employees: Goods-producing Industries (SA, Thous)

All Employees: Logging (SA, Thous)

All Employees: Mining (SA, Thous)

All Employees: Utilities (SA, Thous)

All Employees: Construction (SA, Thous)

All Employees: Manufacturing (SA, Thous)

All Employees: Durable Goods Manufacturing (SA, Thous)

All Employees: Nondurable Goods Manufacturing (SA, Thous)

All Employees: Private Service-providing Industries (SA, Thous)

All Employees: Transportation \& Warehousing (SA, Thous)

All Employees: Retail Trade (SA, Thous)

All Employees: Wholesale Trade (SA, Thous)

All Employees: Financial Activities (SA, Thous)

All Employees: Information Services (SA, Thous)

All Employees: Government (SA, Thous)

ISM Mfg: Employment Index (SA, 50+ = Econ Expand)

Housing Starts (SAAR, Thous.Units)

Housing Starts: Northeast (SAAR, Thous.Units)

Housing Starts: Midwest (SAAR, Thous.Units)

Housing Starts: South (SAAR, Thous.Units)

Housing Starts: West (SAAR, Thous.Units)

New Pvt Housing Units Authorized by Building Permit (SAAR, Thous.Units)

1 ISM Mfg: Inventories Index (SA, 50+ = Econ Expand)

1 ISM Mfg: New Orders Index (SA, 50+ = Econ Expand)

1 ISM Mfg: Supplier Deliveries Index (SA, $50+=$ Slower)

$5 \quad$ S\&P 500 Stock Price Index $(1941-43=10)$

5 S\&P 500 Industrial Stock Price Index $(1941-43=10)$

(1)

5 JP Morgan Narrow Nominal Effective Exchange Rate Index: U.S. $(2000=100)$

5 Foreign Exchange Rate: Switzerland (Swiss Franc/US\$)

5 Foreign Exchange Rate: Japan (Yen/US\$)

5 Foreign Exchange Rate: United Kingdom (US\$/Pound)

3-Month Treasury Bills, Secondary Market (\% p.a.)

6-Month Treasury Bills, Secondary Market (\% p.a.)

1-Year Treasury Bill Yield at Constant Maturity (\%)

5-Year Treasury Note Yield at Constant Maturity (\%)

10-Year Treasury Bond Yield at Constant Maturity (\%)

Moody's Seasoned Aaa Corporate Bond Yield (\% p.a.)

Moody's Seasoned Baa Corporate Bond Yield (\% p.a.)

Shadow rate

1 US6mYield - US3mYield

1 US1yYield - US3mYield

1 US5yYield - US3mYield

1 US10yYield - US3mYield

1 USBAAyield - USAAAyield

2 BOP: Balance on Current Account (SA, Mil.\$)

2 BOP: For Assets in the U.S., Net: Cap Inflow Ex Fin Derivatives $+(\mathrm{SA}, \mathrm{Mil} . \$)$

2 BOP: U.S. Assets Abroad, Net: Outflow Excl Financial Derivatives (-) (SA, Mil.\$)

5 Gross Domestic Product: Chain Price Index (SA, 2009=100) BEA

5 Personal Consumption Expenditures: Chain Price Index (SA, BEA $2009=100)$
BLS

BLS

BLS

BLS

BLS

BLS

BLS

BLS

BLS

BLS

BLS

BLS

BLS

BLS

BLS

BLS

BLS

BLS

ISM

CB

$\mathrm{CB}$

CB

CB

CB

CB

ISM

ISM

ISM

WSJ

S\&P

JP Morgan

FRB

FRB

FRB

FRB

FRB

UST

UST

UST

FRB

FRB

Wu and

Xia 2013

FRB

UST, FRB

UST, FRB

UST, FRB

FRB

BEA

BEA

BEA

0.03
0.48

0.88 


\begin{tabular}{|c|c|}
\hline 83 & USGPDIprices \\
\hline 84 & USExportPrices \\
\hline 85 & USImportPrices \\
\hline 86 & USGprices \\
\hline 87 & USPPIFinGoods \\
\hline 88 & USPPIFinConsGoods \\
\hline 89 & USPPIIntGoods \\
\hline 90 & USPPICrude \\
\hline 91 & USCPIindex \\
\hline 92 & USCPIapparel \\
\hline 93 & USCPIhealth \\
\hline 94 & USCPIxFood \\
\hline 95 & USCPIxHouse \\
\hline 96 & USCPIxHealth \\
\hline 97 & USToT \\
\hline \multicolumn{2}{|c|}{ Monetary aggregates } \\
\hline 98 & USM1 \\
\hline 99 & USM2 \\
\hline 100 & USMonBase \\
\hline \multicolumn{2}{|c|}{ Bank credit (FRB) } \\
\hline 101 & USCommCredit \\
\hline 102 & USCommSecurites \\
\hline 103 & USCommLoans \\
\hline 104 & USCommCILoans \\
\hline 105 & USCommRELoans \\
\hline 106 & USCommConsLoans \\
\hline 107 & USCommOtherLoans \\
\hline \multicolumn{2}{|c|}{ Other FRB indicators } \\
\hline 108 & USWillingnessToLend \\
\hline 109 & USNatActIndex \\
\hline 110 & USConsAndHousing \\
\hline 111 & USEmpUnempHours \\
\hline 112 & USProdAndIncome \\
\hline 113 & USSalesOrdersInvento \\
\hline
\end{tabular}

Gross Private Domestic Investment: Chain Price Index (SA,
$2009=100)$

5 Exports of Goods \& Services: Chain Price Index (SA, 2009=100)

5 Imports of Goods \& Services: Chain Price Index (SA, 2009=100)

5 Govt Consumption Expenditures \& Gross Investment: Chain Price $\operatorname{Index}(\mathrm{SA}, 2009=100)$

5 PPI: Finished Goods (SA, 1982=100)

5 PPI: Finished Consumer Goods $(\mathrm{SA}, 1982=100)$

5 PPI: Intermediate Materials, Supplies and Components (SA, $1982=100)$

5 PPI: Crude Materials for Further Processing (SA, 1982=100) $\quad$ BLS 0.7

5 CPI-U: All Items (SA, 1982-84=100) BLS 0.9

5 CPI-U: Apparel (SA, 1982-84=100) $\quad$ BLS 0.19

5 CPI-U: Medical Care Commodities (SA, 1982-84=100) BLS 0.63

5 CPI-U: All Items Less Food (SA, 1982-84=100) BLS 0.89

5 CPI-U: All Items Less Shelter (SA, 1982-84=100)

5 CPI-U: All Items Less Medical Care (SA, 1982-84=100)

2 Terms of trade index (exports/imports; ratio of chain price indexes for goods and services, SA 2009=100)

5 Money Stock: M1 (SA, Bil.\$)

5 Money Stock: M2 (SA, Bil.\$)

5 Monetary Base (NSA, Mil.\$)

5 Bank Credit: All Commercial Banks (SA, Bil.\$)

5 Securities in Bank Credit: All Commercial Banks (SA, Bil.\$)

5 Loans \& Leases in Bank Credit: All Commercial Banks (SA, Bil.\$)

5 C \& I Loans in Bank Credit: All Commercial Banks (SA, Bil.\$)

5 Real Estate Loans in Bank Credit: All Commercial Banks (SA, Bil.\$)

5 Consumer Loans in Bank Credit: All Commercial Banks (SA, Bil.\$)

5 Other Loans \& Leases in Bank Credit: All Commercial Banks (SA, Bil.\$)

1 FRB Sr Officers Survey: Banks Willingness to Lend to Consumers $(\%)$

1 Chicago Fed National Activity Index (+=Growth Above Trend)

BLS

BLS

0.89

0.89

0.65

1 CFNAI: Personal Consumption \& Housing $(+=$ Growth Above Trend)

1 CFNAI: Employment, Unemployment, \& Hours (+=Growth Above Trend)

1 Chicago Fed National Activity Index: Production \& Income (+=Growth Above Trend)

1 CFNAI: Sales, Orders, \& Inventories $(+=$ Growth Above Trend $)$

FRB $\quad 0.34$

FRB $\quad 0.27$

FRB $\quad 0.4$

FRB $\quad 0.61$

FRB $\quad 0.2$

FRB $\quad 0.71$

FRB $\quad 0.61$

FRB $\quad 0.61$

FRB $\quad 0.07$

$\begin{array}{ll}\text { FRB } & 0.36\end{array}$

FRB $\quad 0.51$

FRB $\quad 0.96$

Chicago

FRB $\quad 0.83$

Chicago

FRB

0.93

Chicago

FRB

0.86

Chicago

FRB

0.78

Confidence, expectations and uncertainty

\begin{tabular}{|c|c|c|c|c|c|}
\hline 114 & USConfidence & 5 & Conference Board: Consumer Confidence (SA, 1985=100) & $\begin{array}{l}\text { Conference } \\
\text { Board }\end{array}$ & 0.39 \\
\hline 115 & USConfidencePresent & 5 & $\begin{array}{l}\text { Conference Board: Consumer Confidence Present Situation (SA, } \\
1985=100)\end{array}$ & $\begin{array}{l}\text { Conference } \\
\text { Board }\end{array}$ & 0.62 \\
\hline 116 & USConfidenceExpectations & 5 & Conference Board: Consumer Expectations (SA, 1985=100) & $\begin{array}{l}\text { Conference } \\
\text { Board }\end{array}$ & 0.26 \\
\hline 117 & USMichConfidence & 1 & U Michigan: Consumer Sentiment (NSA, Q1-66=100) & U Michigan & 0.66 \\
\hline 118 & USMichConfidenceCurr & 1 & U Michigan: Current Economic Conditions (NSA, Q1-66=100) & U Michigan & 0.73 \\
\hline 119 & USUMichConfidenceExp & 1 & U Michigan: Consumer Expectations (NSA, Q1-66=100) & U Michigan & 0.58 \\
\hline 120 & USVIX & 5 & $\begin{array}{l}\text { CBOE Market Volatility Index, VIX; extended with standard de- } \\
\text { viation of SP index }\end{array}$ & WSJ & 0.18 \\
\hline 121 & USVXO & 5 & $\begin{array}{l}\text { CBOE Market Volatility Index, VXO; extended with Bloom un- } \\
\text { certainty measure }\end{array}$ & WSJ & 0.19 \\
\hline \multicolumn{6}{|c|}{ 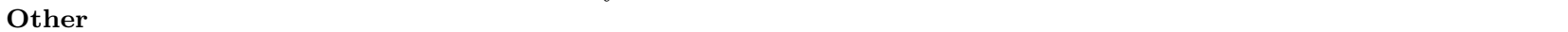 } \\
\hline 122 & GZLT & 1 & Excess Bond Premium (values after Sep-10 are forecast by us) & GZ & 0.56 \\
\hline
\end{tabular}

National accounts 


\begin{tabular}{|c|c|}
\hline 123 & CANrGDP \\
\hline 124 & CANrExports \\
\hline 125 & CANrImports \\
\hline 126 & $\mathrm{CANrC}$ \\
\hline 127 & CANrI \\
\hline 128 & CANrGC \\
\hline 129 & CANrGI \\
\hline GDP & by NAICS \\
\hline 130 & CANryGoods \\
\hline 131 & CANryAgr \\
\hline 132 & CANryMin \\
\hline 133 & CANryUtl \\
\hline 134 & CANryCon \\
\hline 135 & CANryMan \\
\hline 136 & CANrySvc \\
\hline 137 & CCANryWht \\
\hline 138 & CANryRet \\
\hline 139 & CANryTrn \\
\hline 140 & CANryInf \\
\hline 141 & CANryPro \\
\hline 142 & CANryAdm \\
\hline 143 & CANryEdu \\
\hline 144 & CANryHlt \\
\hline 145 & CANryArt \\
\hline 146 & CANryAcc \\
\hline 147 & CANryOth \\
\hline 148 & CANryPub \\
\hline Trad & e flows by NAPCS \\
\hline 149 & CANrGoodsExports \\
\hline 150 & CANrAgrExports \\
\hline 151 & CANrEnergyExports \\
\hline 152 & CANrOreExports \\
\hline 153 & CANrMetalExports \\
\hline 154 & CANrChemExports \\
\hline 155 & CANrForExports \\
\hline 156 & CANrIndExports \\
\hline 157 & CANrElecExports \\
\hline 158 & CANrAutoExports \\
\hline 159 & CANrTranspExports \\
\hline
\end{tabular}

5 Canada: Gross Domestic Product at Market Prices (SAAR, Statcan Mil.Chn.2007.C\$)

5 Canada: GDP: Exports of Goods and Services: Total (SAAR, Statcan Mil.Chn.2007.C\$)

5 Canada: GDP: Imports of Goods and Services: Total (SAAR, Statcan Mil.Chn.2007.C\$)

5 Canada:GDP: Household Final Consumption Exp: Total (SAAR, Statcan Mil.Chn.2007.C\$)

5 Canada: GDP: Business Gross Fixed Capital Formation (SAAR, Statcan Mil.Chn.2007.C\$)

5 Canada:GDP: General Govt Final Consumption Expenditure Statcan (SAAR,Mil.Chn.2007.C \$)

5 Canada: GDP: Gross Fixed Capital Form: General Govern- Statcan ment(SAAR, Mil.Chn.2007.C\$)

5 Canada: GDP: Goods-Producing Industries (SAAR, Mil.2007.C\$) Statcan

5 Canada: GDP: Agriculture, Forestry, Fishing and Hunting Statcan (SAAR, Mil.2007.C $\$$ )

5 Canada: GDP: Mining, Quarrying, and Oil and Gas Extraction Statcan (SAAR, Mil.2007.C $\$$ )

5 Canada: GDP: Utilities (SAAR, Mil.2007.C\$) Statcan

5 Canada: GDP: Construction (SAAR, Mil.2007.C\$)

5 Canada: GDP: Manufacturing (SAAR, Mil.2007.C\$) Canada: GDP: Service-Producing Industries (SAAR, Statcan Mil.2007.C\$)

5 Canada: GDP: Wholesale Trade (SAAR, Mil.2007.C\$) Statcan

5 Canada: GDP: Retail Trade (SAAR, Mil.2007.C\$) Statcan

5 Canada: GDP: Transportation and Warehousing (SAAR, Statcan Mil.2007.C\$)

5 Canada: GDP: Information and Cultural Industries (SAAR, Statcan Mil.2007.C\$)

5 Canada: GDP: Professional, Scientific and Technical Ser- Statcan vices(SAAR, Mil.2007.C\$)

5 Can:GDP:Admin $\backslash$ Support, Waste Management \& Remediation Statcan Service(SAAR,Mil.2007.C\$)

5 Canada: GDP: Educational Services (SAAR, Mil.2007.C\$) Statcan

5 Canada: GDP: Health Care and Social Assistance (SAAR, Statcan Mil.2007.C\$)

5 Canada: GDP: Arts, Entertainment and Recreation (SAAR, Statcan Mil.2007.C\$)

5 Canada: GDP: Accommodation and Food Services (SAAR, Statcan Mil.2007.C\$)

5 Canada: GDP: Other Services (Except Public Administration) Statcan (SAAR, Mil.2007.C\$)

5 Canada: GDP: Public Administration (SAAR, Mil.2007.C\$) Statcan

0.41

0.79

0.54

0.16

0.48

0.32

0.31

0.16

0.1

0.18

0.1

0.19

0.28

5 Canada: Total Exports of Goods (SAAR, Mil.Chn.2007.C\$)

Statcan $\quad 0.25$

Statcan

0.64 ucts(SAAR, Mil.Chn.2007.C\$)

5 Canada: Exports of Energy Products (SAAR, Mil.Chn.2007.C\$) Statcan

5 Canada: Exports of Metal Ores and Nonmetallic Minerals (SAAR, Statcan Mil.Chn.2007.C\$)

5 Canada: Exports of Metal and Nonmetallic Mineral Prod- Statcan ucts(SAAR, Mil.Chn.2007.C\$)

5 Canada: Exp of Basic \& Ind Chem, Plastics \& Rubber Statcan Prods(SAAR, Mil.Chn.2007.C $\$$ )

5 Canada: Exports of Forestry Prods \& Bldg \& Packaging Statcan Mtls(SAAR, Mil.Chn.2007.C\$)

5 Canada: Exports of Industrial Machinery, Equip \& Parts (SAAR, Statcan Mil.Chn.2007.C\$)

5 Canada: Exports of Electronic \& Electrical Equip \& Parts Statcan (SAAR, Mil.Chn.2007.C\$)

5 Canada: Exports of Motor Vehicles and Parts (SAAR, Statcan Mil.Chn.2007.C $\$$ )

5 Canada: Exports of Aircraft \& Other Transp Eqpt \& Parts Statcan (SAAR, Mil.Chn.2007.C\$) 


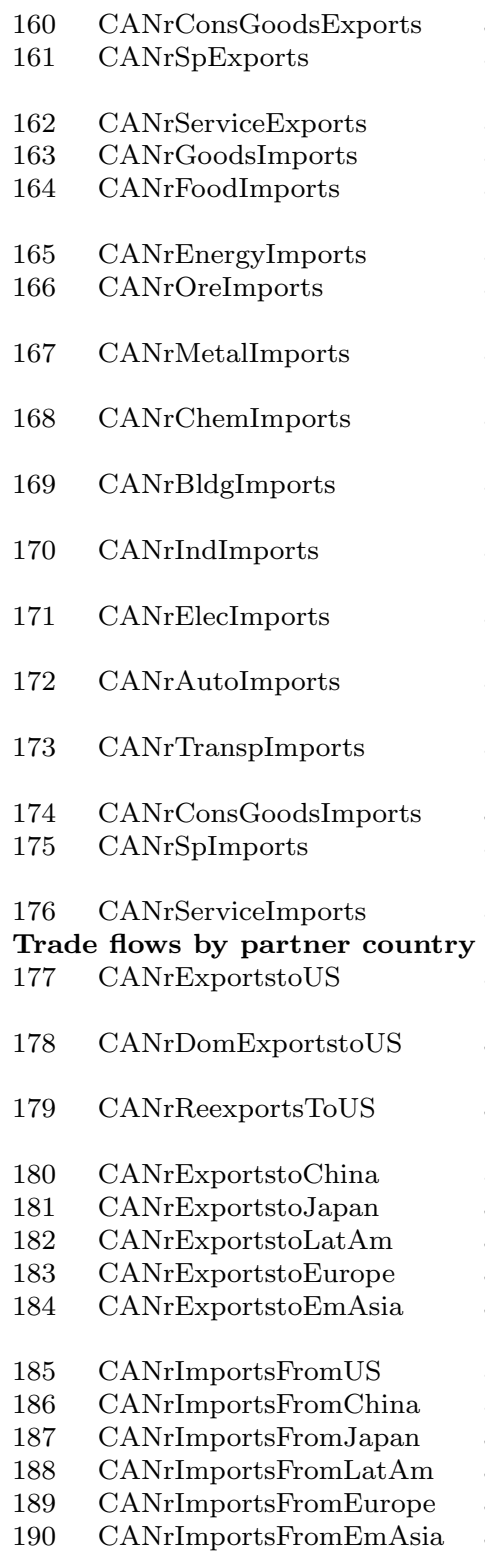

$\begin{array}{ll}\text { Real output and income } \\ 191 & \text { CANIP } \\ \text { Employment } \\ 192 & \text { CANEmp } \\ & \\ 193 & \text { CANEmpGoods } \\ 194 & \text { CANEmpAgr } \\ 195 & \text { CANEmpMinFor } \\ & \\ 196 & \text { CANEmpCon } \\ 197 & \text { CANEmpMan } \\ 198 & \text { CANEmpUtl } \\ 199 & \text { CANEmpSvc } \\ 200 & \text { CANEmpTrade } \\ 201 & \text { CANEmpTrn } \\ 202 & \text { CANEmpFin }\end{array}$

5 Canada: Exports of Consumer Goods (SAAR, Mil.Chn.2007.C\$)

5 Canada: Exports of Special Transactions (SAAR, Statcan Mil.Chn.2007.C\$)

5 Canada: Total Exports of Services (SAAR, Mil.Chn.2007.C\$) Statcan

5 Canada: Total Imports of Goods (SAAR, Mil.Chn.2007.C\$) Statcan

5 Canada: Imports of Farm, Fishing \& Intermed Food Prod- Statcan ucts(SAAR, Mil.Chn.2007.C\$)

5 Canada: Imports of Energy Products (SAAR, Mil.Chn.2007.C\$) Statcan

5 Canada: Imports of Metal Ores and Nonmetallic Minerals (SAAR, Statcan Mil.Chn.2007.C\$)

5 Canada: Imports of Metal and Nonmetallic Mineral Prod- Statcan ucts(SAAR, Mil.Chn.2007.C\$)

5 Canada: Imp of Basic \& Ind Chem, Plastics \& Rubber Statcan Prods(SAAR, Mil.Chn.2007.C $\$$ )

5 Canada: Imports of Forestry Prods \& Bldg \& Packaging Statcan Mtls(SAAR, Mil.Chn.2007.C\$)

5 Canada: Imports of Industrial Machinery, Equip \& Parts (SAAR, Statcan Mil.Chn.2007.C\$)

5 Canada: Imports of Electronic \& Electrical Equip \& Parts Statcan (SAAR, Mil.Chn.2007.C\$)

5 Canada: Imports of Motor Vehicles and Parts (SAAR, Statcan Mil.Chn.2007.C\$)

5 Canada: Imports of Aircraft \& Other Transp Eqpt \& Parts Statcan (SAAR, Mil.Chn.2007.C $\$$ )

5 Canada: Imports of Consumer Goods (SAAR, Mil.Chn.2007.C\$) Statcan 5 Canada: Imports of Special Transactions (SAAR, Statcan Mil.Chn.2007.C $\$$ )

5 Canada: Total Imports of Services (SAAR, Mil.Chn.2007.C\$) Statcan

5 Canada: Total Merchandise Exports: United States (NSA, Mn. Statcan 2007 C $\$$

5 Canada: Domestic Merchandise Exports to the U.S. (NSA, Mn. Statcan $2007 \mathrm{C} \$$ )

5 Canada: Merchandise Re-Exports to the U.S. (NSA, Mn. 2007 Statcan $\mathrm{C} \$)$

5 Total merch. exports to China (NSA, Mn.C\$2007) Statcan

5 Total merch. exports to Japan (NSA, Mn.C\$2007)

5 Total merch. exports to Latin America (NSA, Mn.C\$2007)

5 Total merch. exports to Europe (NSA, Mn.C\$2007)

5 Total merch. exports to Emerging Asia ex. China (NSA, Mn.C\$ 2007)

5 Total merch. imports from the US (NSA, Mn.C\$2007)

Statcan

Statcan

Statcan

Statcan

Statcan

Statcan

Total merch. imports from China (NSA, Mn.C\$2007)

Total merch. imports from Japan (NSA, Mn.C\$2007)

Total merch. imports from Latin America (NSA, Mn.C\$ 2007)

Total merch. imports from Europe (NSA, Mn.C\$2007)

Statcan

Statcan

Statcan

Total merch. imports from Emerging Asia ex. China (NSA, Statcan Mn.C\$2007)

5 Canada: GDP: Industrial Production (SAAR, Mil.2007.C\$)

Statcan

5 Canada: Employment: Both Sexes, 15 Years and Over (SA, Statcan Thous)

5 Canada: Employment: Goods Producing Sector (SA, Thous) Statcan Canada: Employment: Agriculture (SA, Thous) Statcan

Canada: Employment: Forestry, Fishing, Mining, Oil \& Gas (SA, Statcan Thous)

5 Canada: Employment: Construction (SA, Thous) Statcan Canada: Employment: Manufacturing (SA, Thous)

Canada: Employment: Utilities (SA, Thous)

Canada: Employment: Service Producing Sector (SA, Thous)

Canada: Employment: Trade (SA, Thous)

Canada: Employment: Transport and Warehousing (SA, Thous)

Canada: Employment: Finance, Insurance, Real Estate (SA, Thous)
0.77

0.75

0.35

0.14

0.21

0.62

0.02

0.21

0.09

0.37

0.27

0.2

0.42

0.43

0.45

0.11

0.42

0.1

0.4

0.87

0.85

0.42

0.27

0.26

0.15

0.4

0.41

0.73

0.59

0.19

0.36

0.28

0.34

0.68

0.14

0.22

0.52

0.55

0.16

0.52

0.31

0.23

0.12 


\begin{tabular}{|c|c|}
\hline 203 & CANEmpPro \\
\hline 204 & CANEmpAdm \\
\hline 205 & CANEmpEdu \\
\hline 206 & CANEmpHlt \\
\hline 207 & CANEmpInf \\
\hline 208 & CANEmpAcc \\
\hline 209 & CANEmpOth \\
\hline 210 & CANEmpPub \\
\hline Ho & ing \\
\hline 211 & CANNewHousePrice \\
\hline 212 & CANHousingStarts \\
\hline Sto & prices \\
\hline 213 & CANTSXindex \\
\hline 214 & CANTSXDivYield \\
\hline Exc & ange rates \\
\hline 215 & CANNEER \\
\hline 216 & USDzCAD \\
\hline Int & est rates \\
\hline 217 & CAN3mYield \\
\hline 218 & CAN6mYield \\
\hline 219 & CAN1to3yYield \\
\hline 220 & CAN3to5yYield \\
\hline 221 & CAN5to10yYield \\
\hline 222 & CAN10yYield \\
\hline 223 & CAN3mCorpYield \\
\hline 224 & CAN6mSpread \\
\hline 225 & CAN1to3ySpread \\
\hline 226 & CAN3to5ySpread \\
\hline 227 & CAN5to10ySpread \\
\hline 228 & CAN10ySpread \\
\hline 229 & CAN3mCorpSpread \\
\hline $\mathrm{Bal}$ & nce of payments \\
\hline 230 & CANCurrAcctBal \\
\hline 231 & CANFDIassets \\
\hline 232 & CANPortfolioAssets \\
\hline 233 & CANFDIliabilities \\
\hline 234 & CANPortfolioLiabilities \\
\hline 235 & CANFDIassetsUS \\
\hline 236 & CANPortfolioAssetsUS \\
\hline 237 & CANFDIliabilitiesUS \\
\hline 238 & CANPortfolioLiabilitiesUS \\
\hline Pri & indexes \\
\hline 239 & CANIndPriceIndex \\
\hline 240 & CANIntGoodsPriceIndex \\
\hline 241 & CANFinGoodsPriceIndex \\
\hline 242 & CANBCPI \\
\hline 24 & CANCPI \\
\hline & CANcoreCPI \\
\hline
\end{tabular}

5 Canada: Employment: Professional, Scientific \& Technical (SA, Statcan Thous)

5 Canada: Employment: Business, Building \& Other Support Ser- Statcan vices (SA, Thous)

5 Canada: Employment: Educational Services (SA, Thous) Statcan

5 Canada: Employment: Health Care and Social Assistance (SA, Statcan Thous)

5 Canada: Employment: Information, Culture and Recreation (SA, Statcan Thous)

5 Canada: Employment: Accommodation and Food Services (SA, Statcan Thous)

5 Canada: Employment: Other Services (SA, Thous) Statcan

5 Canada: Employment: Public Administration (SA, Thous) Statcan

5 Canada: New Housing Price, Total House \& Land (NSA, Statcan $2007=100)$

4 Canada: Housing Starts: All Areas (NSA, Units)

$\mathrm{CMHC}$

5 Canada: Nominal Narrow Effective Exch Rate (Avg, 2010=100)

5 Canada: US Dollar Exchange Rate: Close (AVG, US\$/C $\$$ )

BIS

$\mathrm{BoC}$

0.61

Canada: Treasury Bills: 3-Months (AVG, \%)

1 Canada: Treasury Bills: 6-Months (AVG, \%)

1 Canada: 1 to 3 Year Bond Yield Average (Last Wednesday, \%)

Canada: 3 to 5 Year Bond Yield Average (Last Wednesday, \%)

1 Canada: 5 to 10 Year Bond Yield Average (Last Wednesday, \%)

1 Canada: 10-Year \& Over Bond Yield Average (Last Wednesday, $\%)$

1 Canada: Prime Corporate Paper: 3-Months (AVG, \%)

1 CAN6mYield - CAN3mYield

1 CAN1to3yYield - CAN3mYield

1 CAN3to5yYield - CAN3mYield

1 CAN5to10yYield - CAN3mYield

1 CAN10yYield - CAN3mYield

1 CAN3mCorpSpread - CAN3mYield

$\mathrm{BoC}$

$\mathrm{BoC}$

$\mathrm{BoC}$

$\mathrm{BoC}$

$\mathrm{BoC}$

$\mathrm{BoC}$

$\mathrm{BoC}$

$\mathrm{BoC}$

$\mathrm{BoC}$

$\mathrm{BoC}$

$\mathrm{BoC}$

$\mathrm{BoC}$

$\mathrm{BoC}$

Statcan

Statcan (NSA, Mil.C\$)

2 Canada: BOP: Canadian Direct Investment Abroad: Total (NSA, Mil.C\$)

2 Canada: BOP: Canadian Portfolio Investment: Total (NSA, Statcan Mil.C\$)

2 Canada: BOP: Foreign Direct Investment in Canada: Total (NSA, Statcan Mil.C\$)

2 Canada: BOP: Foreign Portfolio Investment: Total (NSA, Mil.C\$) Statcan

2 Canada: BOP: Canadian Direct Investment Abroad: United Statcan States (NSA, Mil.C\$)

2 Canada: BOP: Canadian Portfolio Investment: United States Statcan (NSA, Mil.C\$)

2 Canada: BOP: Foreign Direct Investment in Canada: United Statcan States (NSA, Mil.C\$)

2 Canada: BOP: Foreign Portfolio Investment: United States (NSA, Statcan Mil.C\$)

5 Canada: Industrial Product Price Index: Total (NSA, 2010=100) Statcan 5 Canada: Industrial Price Index: Intermediate Goods (NSA, Statcan $2002=100)$

5 Canada: Industrial Price Index: Finished Goods (NSA, Statcan $2002=100)$

5 Canada: Chain Fisher BoC Commodity Price Index (NSA, Jan- BoC

$\mathrm{BoC} \quad 0.74$ $72=100)$

5 Canada: Consumer Prices $(2005=100$, NSA)

5 Canada: BoC Core CPI [V41690925] $(\mathrm{SA}, 2002=100)$ 


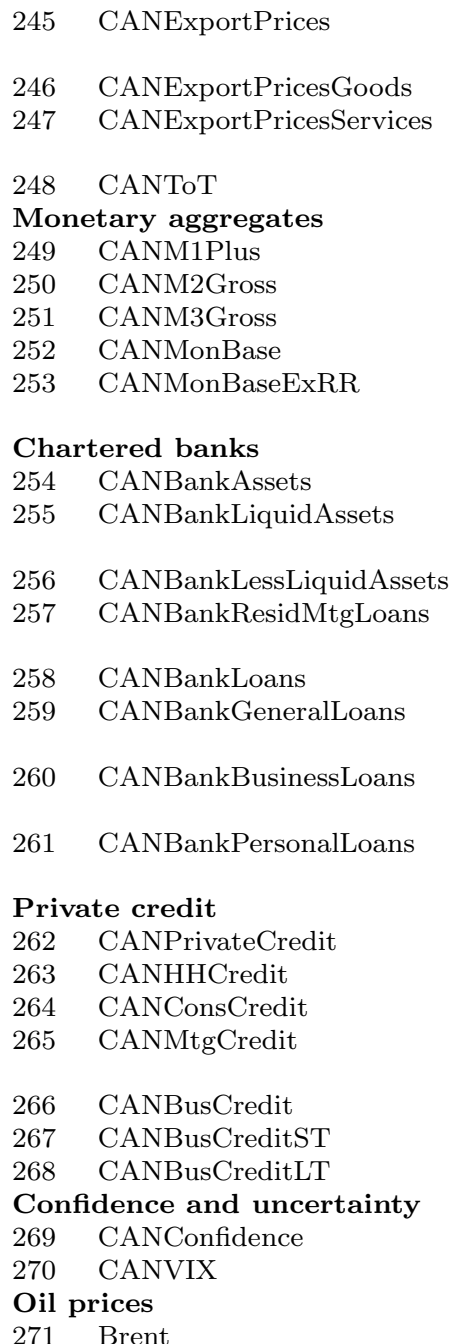

271 Brent
5 Canada: Implicit Price Index: Exports of Goods and Svcs(SA, Statcan $2007=100)$

5 Canada: Implicit Price Index: Exports of Goods (SA, 2007=100) Statcan Canada: Implicit Price Index: Exports of Services (SA, Statcan $2007=100)$

5 Canada: Terms of Trade Index (SA, 2007=100) Statcan

0.46

0.67

Canada: $\mathrm{M} 1+(\mathrm{SA}, \mathrm{Mil} . \mathrm{C} \$)$

Canada: M2 Gross [V41552796] (SA, Avg, Mil.C\$)

Canada: M3 Gross [V41552794] (SA, Avg, Mil.C\$)

$\mathrm{BoC}$

$\mathrm{BoC}$

$\mathrm{BoC}$

$\mathrm{BoC}$

Canada: Monetary Base (SA, Mil.C\$)

Canada: Monetary Base Excluding Required Reserves (SA, BoC Mil.C\$)

5 Canada: Chartered Banks: Major Assets (Avg, SA, Mil.C\$)

$\mathrm{BoC}$

$\mathrm{BoC}$

(Avg, SA, Mil.C\$)

Canada: Canadian Dollar Assets, Less Liquid Assets (Mil.C\$)

$\mathrm{BoC}$

$\mathrm{BoC}$ (SA, Mil.C\$)

5 Canada: Chartered Bank Assets: Bank Loans (SA, Mil.C\$) BoC

$\mathrm{BoC}$
$\mathrm{BoC}$

Canada: Genl Loans

5 Canada: Chartered Bank Assets: Business Loans (SA, Avg Weds, BoC Mil.C\$)

5 Canada: Chartered Bank Assets: Total Personal Loans (SA, Avg BoC Weds, Mil.C\$)

Canada: Business and Household Credit (SA, Mil.C\$)

$\mathrm{BoC} \quad 0.71$

Canada: Household Credit (SA, Mil.C\$)

Canada: Consumer Credit at Month-End (EOP, SA, Mil.C\$)

$\mathrm{BoC}$

$\mathrm{BoC}$

$\mathrm{BoC}$

$\mathrm{BoC}$ Mil.C\$)

5 Canada: Business Credit (SA, Mil.C\$)

5 Canada: Short-Term Business Credit (SA, Mil.C\$)

5 Canada: Long-Term Business Credit (SA, Mil.C\$)

$\mathrm{BoC}$

$\mathrm{BoC}$

$\mathrm{BoC}$

$\mathrm{BoC}$

BoC 